\title{
Body shape changes associated with reproductive status, nutritive condition and growth in right whales Eubalaena glacialis and E. australis
}

\author{
Carolyn A. Miller ${ }^{1, *}$, Peter B. Best ${ }^{2}$, Wayne L. Perryman ${ }^{3}$, Mark F. Baumgartner ${ }^{1}$, \\ Michael J. Moore ${ }^{1}$ \\ ${ }^{1}$ Biology Department, Woods Hole Oceanographic Institution, Woods Hole, Massachusetts 02543, USA \\ ${ }^{2}$ Mammal Research Institute, University of Pretoria, c/o Iziko South African Museum, PO Box 61, Cape Town, South Africa \\ ${ }^{3}$ Southwest Fisheries Science Center, National Marine Fisheries Service, National Oceanic and Atmospheric Administration, \\ PO Box 271, La Jolla, California 92038, USA
}

\begin{abstract}
Mammalian reproduction is metabolically regulated; therefore, the endangered status and high variability in reproduction of North Atlantic right whales Eubalaena glacialis necessitate accurate assessments at sea of the nutritional condition of living individuals. Aerial photogrammetry was used to measure dorsal body width at multiple locations along the bodies of free-swimming right whales at different stages of the female reproductive cycle (E. glacialis) and during the initial months of lactation (mother and calf Eubalaena australis) to quantify changes in nutritional condition during energetically demanding events. Principal components analyses indicated that body width was most variable at $60 \%$ of the body length from the snout. Thoracic, abdominal and caudal body width of E. australis thinned significantly during the initial months of lactation, especially at $60 \%$ of body length from the snout, while their calves' widths and widthto-length ratios increased. The body shape of E. glacialis that had been lactating for 8 mo was significantly thinner than non-lactating, non-pregnant E. glacialis. Body shape of E. glacialis measured in the eighth month of lactation was significantly thinner than that of E. australis in the first month, but did not differ from that of $E$. australis in the third and fourth months. Body width was comparable with diameter calculated from girth of carcasses. These results indicate that mother right whales rely on endogenous nutrient reserves to support the considerable energy expenditure during the initial months of lactation; therefore, photogrammetric measurements of body width, particularly at $60 \%$ of body length from the snout, are an effective way to quantitatively and remotely assess nutritional condition of living right whales.
\end{abstract}

KEY WORDS: Right whale ' Body shape - Body condition - Aerial photogrammetry · Reproduction · Energetics $\cdot$ Eubalaena

Resale or republication not permitted without written consent of the publisher

\section{INTRODUCTION}

Right whales were depleted worldwide by the mid19th century (IWC 2001) and only received international protection in 1935. Recovery has been observed in several populations of the southern right whales Eubalaena australis, including that off South Africa, but has been much slower in northern right whales (E. glacialis in the North Atlantic and E. japonica in the North Pacific oceans) (IWC 2001). The South African population comprised approximately 3100 individual whales in 1997 (IWC 2001) and was growing at a rate of $6.8 \% \mathrm{yr}^{-1}$ during 1971 to 1998 , which is close to its biological maximum (Best et al. 2001), while the North Atlantic population was estimated at a minimum number of 325 in 2007 (NOAA 
2009) and had an annual growth rate of $1.8 \%$ between 1990 and 2005 (NOAA 2009). Mortalities from vessel strikes and fishing gear entanglements (Knowlton \& Kraus 2001) influence the recovery rate of North Atlantic right whales but do not fully account for the reduced growth rate; variable reproductive rates also may be a contributing factor (Kraus et al. 2001, 2007, Reeves et al. 2001).

Fertility is affected by body fat reserves in mammals including other large whale species (Marshall \& Hammond 1926, Frisch 1984, Lockyer 1986, 1987, Thomas 1990) and trends in blubber thickness correspond to the reproductive cycle of female right whales Eubalaena glacialis (Miller et al. 2011). Reproduction is energetically costly, particularly for mammals that fast during reproductive events (Young 1976, Lockyer 1981, Frisch 1984, Gittleman \& Thompson 1988, Thomas 1990). One way such energetic costs can be mitigated is by increasing body fat reserves prior to conception (Frisch 1984). A preconception increase in adiposity has been observed in right whales and gray whales Eschrichtius robustus; Eubalaena glacialis females before the start of pregnancy had the thickest blubber of all life history categories measured (Miller et al. 2011), and the blubber of recently ovulated gray whales was thicker than that of immature whales, adult males and adult anoestrous and postpartum females but similar in thickness to that of females in the early and late stages of pregnancy (Rice \& Wolman 1971). Although adiposity is critical to reproductive function, reproduction is metabolically regulated through a complex array of signals affected by short- and long-term changes in nutrition and energy balance (see Wade \& Schneider 1992, Prunier \& Quesnel 2000, Barb et al. 2001, 2008, Hill et al. 2008 for reviews). As such, it is important to assess overall nutritive condition of an animal when considering reproductive function.

Lactation was calculated as the costliest part of the reproductive cycle in large whales (Lockyer 1981), and in other mammals lactation has been estimated to require 3 to 5 times more energy than gestation (Young 1976). Right whale mothers do not appear to feed while in the calving habitats and consequently are believed to support their calves and themselves with endogenous nutrient reserves during the initial months of lactation. However, because traditional methods used to assess nutritional and metabolic status biochemically cannot be applied to freeswimming whales, little is known about the biochemical adaptations to fasting in whales, particularly during periods of considerable energy expenditure, such as lactation.
Measurements of body girth and width integrate major structural components that can vary in volume with nutrition, such as integument, muscle and abdominal and thoracic adipose tissue. Cetacean body girth (measured directly on carcasses) varied among years in which differences in prey abundance, quality and/or composition were observed (Lockyer 1986, 1987, Read 1990, Ichii et al. 1998, Haug et al. 2002). Also, differences in body width (measured remotely using aerial photogrammetry) of migrating gray whales were associated with the presumed fasting that occurs during the winter migration (Perryman \& Lynn 2002). Moreover, body girth and width of large whales varied among whales of differing reproductive status (Lockyer et al. 1985, Lockyer 1987, Perryman \& Lynn 2002). Hence, nutritive condition of whales may be assessed by directly measuring body girth of carcasses or by remotely measuring body width of free-swimming whales.

The caudal region of the body appears to be an important area of lipid storage in balaenopterids (Feltmann et al. 1948, Lockyer et al. 1984, 1985, Næess et al. 1998). Similarly, in gray whales the location of maximum body width of parturient females and females in the initial months of lactation was significantly more caudal than in other adults, juveniles and females in the later stages of lactation (Perryman \& Lynn 2002). However, for right whales, blubber thickness (an index of body fat condition) was measured (Miller et al. 2011) and the external appearance (a proxy of nutritive condition) was assessed (Pettis et al. 2004 ) only on the cranial region of the body, particularly between 30 and $50 \%$ of the body length from the snout. Little is known about the patterns of lipid storage and utilization and nutritive condition along the entire length of the right whale body.

Long-term research and monitoring of right whales in the North Atlantic Ocean and off the coast of South Africa has resulted in extensive life history and sighting databases of individually identified whales. This enables comparison of life histories with field measures of nutritional condition for individual whales. We used images collected in previous aerial photogrammetric studies (Best \& Rüther 1992, W. L. Perryman unpubl. data) to measure, by means of aerial photogrammetry, dorsal body width at 8 locations along the bodies of adult female right whales of differing reproductive status and of Eubalaena australis neonates and calves during early growth. Adult female $E$. australis were photographed in the first month and again in the third and/or fourth month of lactation, the period of lactation during which female right whales fast. Adult female E. glacialis were pho- 
tographed a few months prior to the start of pregnancy, during late pregnancy, during late lactation (after feeding had resumed), during the resting years or as nulliparous females (older than mean age of first parturition yet had never been observed in close and consistent association with a calf during their sighting histories). Based on the evidence that energetically costly events, such as lactation, results in changes in body composition (indicative of changes in nutritive condition) of right whales (Miller et al. 2011) and other large whales (e.g. Rice \& Wolman 1971, Lockyer et al. 1985, Lockyer 1986, 1987, Aguilar \& Borrell 1990, Næss et al. 1998, Haug et al. 2002), we measured the dorsal body shapes of the aforementioned adult females of varying reproductive status to (1) determine if differences in dorsal body shape among female right whales of differing reproductive status and, hence, differing nutritional condition, can be detected; and if so, (2) quantify such changes in dorsal body shape associated with reproduction, particularly with regards to stage of lactation; and (3) determine the locations along the adult female body most indicative of nutritive condition. We also describe changes in calf body shape during the initial months of life, a time of rapid growth, and finally, we provide perspective on how measurements of dorsal body width of freeswimming right whales relate to measurements of body girth on right whale carcasses. In this way, we aim to: (1) quantify the effects of reproduction on nutritional condition to provide a better understanding of the reproductive variability in E. glacialis; and (2) validate that aerial photogrammetric measurements of body shape can be used to remotely assess and monitor nutritive condition of right whales and, therefore, provide essential information for the development and implementation of successful management strategies to aid in the conservation of North Atlantic right whales.

\section{MATERIALS AND METHODS}

\section{Field collection of photographs}

Vertical aerial photographs of Eubalaena glacialis were collected with a $126 \mathrm{~mm}$ format KA76 military reconnaissance camera (image size, $114 \times 114 \mathrm{~mm}$ ) from a Twin Otter airplane during 2 flights in August 2000, 3 flights in August 2001 and 4 flights in August 2002 in the Bay of Fundy, eastern Canada. The camera was mounted vertically over a camera port in the deck of the aircraft and was operated by an observer stationed at the right forward bubble window. As each photograph was taken, a computer-based data acquisition system recorded time, GPS position and altitude from a Honeywell AA300 series radar altimeter. Altitudes for photo passes ranged between 150 and $250 \mathrm{~m}$. Camera cycle rate was adjusted to provide 60 to $80 \%$ overlap between successive images. The photographs used in the study were taken with Kodak Aerochrome HS film (SO-359).

Vertical aerial photographs of Eubalaena australis mothers and calves were collected with a Hasselblad ELM on Ektachrome 200 ASA film from a helicopter offshore from the De Hoop Nature Reserve, South Africa, on 28 July, 26 September and 13 October 1989: details of the aircraft, camera systems and image collection protocols have been previously reported (Best \& Rüther 1992).

\section{Identification and classification of whales}

Individual adult whales were identified by the patterns of head callosities, scarring, and skin pigmentation (Payne et al. 1983, Kraus et al. 1986), whereas calves were recognized by their association with known females. Only images of known adult females (females for which life history data were available) were chosen for measurement of Eubalaena glacialis. Life history information on E. glacialis was obtained from the Photo-Identification Catalog Dataset of the North Atlantic Right Whale Consortium Database, version dated 29 June 2004 (Right Whale Consortium 2004). For E. australis, only individual whales photographed in at least 2 different months (i.e. on more than one flight) were chosen for measurement. To ensure that there would be no biases, measurements were made blind to individual whale identity, flight date (for E. australis) and reproductive status (for $E$. glacialis).

Eubalaena glacialis females were classified retrospectively according to their reproductive status (lactating, pregnant, pre-pregnant, resting, or nulliparous) at the time the photographs were taken. Lactating females were whales that had produced a calf during the winter calving season (December to February) and had been sighted consistently with that calf throughout the year of photographic sampling. Since lactation lasts approximately 10 to $12 \mathrm{mo}$ (Hamilton et al. 1995) and the lactating females were photographed in summer (August), these females were considered to be in the later stages of lactation. Pregnant females were whales that calved during the winter calving season immediately after the summer 
during which they were photographed, since length of gestation is approximately $1 \mathrm{yr}$ (Best 1994). Prepregnant females were whales that produced a calf in a winter calving season approximately 14 mo after photographic sampling in August and, thus, were photographed 3 to 6 mo prior to the start of pregnancy. Resting females were females that had produced a calf previously in their sighting history and were not classified as pre-pregnant, pregnant or lactating. Nulliparous females were females that were older than the mean age of first parturition, $9.5 \mathrm{yr}$ (Kraus et al. 2001) and had never been observed in close and consistent association with a calf during their sighting histories, although a fetus could have been aborted or a calving missed.

Eubalaena australis were classified as mothers if observed in close, consistent association with a calf. Calves were determined by their small size and close, consistent association with a large whale, the presumed mother. Since the winter calving season of $E$. australis extends from late June to late October (Best 1994) and the mothers and calves were photographed at the end of July and again at the end of September and/or October, the mothers and calves were considered to have been photographed within the first few weeks of lactation/suckling and subsequently a minimum of $2 \mathrm{mo}$ and a maximum of $4 \mathrm{mo}$ into lactation/suckling.

\section{Measurements from photographs}

Negatives were reviewed on a light table to select for whales that were near the surface, dorsal side up and clearly visible. Images of Eubalaena glacialis were captured and transferred to a computer by using a high resolution digital camera (SPOT or SPOT Insight Color, Diagnostic Instruments) mounted above the light table. Images of E. australis were digitally acquired by using a color image scanner (Canoscan 9900, Canon USA).

For each image, body length (snout to fluke notch) of the whale was measured. Then body width (distance between the lateral edges of the whale) was measured at sites every $10 \%$ of the body length from the snout except the $90 \%$ sites, as this occurred at the insertion of the flukes. Images were measured digitally by using Image Pro Plus v. 4.5.1.29 (Media Cybernetics). The segmentation of the whale to identify measurement site was automated by percentage of user-defined endpoints of whale length (snout and fluke notch) by using a custom code written for Image Pro Plus v. 4.5.1.29. At times, one or both sides of the whales were not clearly visible because of water distortion, shadow and/or diminished water clarity. If only one side was affected but the outline of the whale remained visible, the measurement was taken and included in the analyses. If a width edge was not discernible or if both sides of the whale were affected at a particular measurement site, width was not measured. In rare instances, the outline of the whale was clearly visible but one endpoint of body length was not; in that case, the average length from other images of the same individual sampled in the same season (Eubalaena glacialis) or flight (E. australis) was calculated and used to measure and mark the location of the missing endpoint on the image. Distances measured on the computer image were multiplied by the scale of the photograph (scale = altitude/ lens focal length) to obtain true measurements. Methods for calibrating scale for the images of $E$. australis were provided by Best \& Rüther (1992). For E. glacialis, bias in readings from the radar altimeter was corrected based on linear regression of altitudes calculated from measurements of known length sections of PVC pipe deployed at sea (for technique see Perryman \& Lynn 2002).

\section{Precision of estimates}

The precision of the estimates was determined by calculating the coefficients of variation (CVs) for individual whales measured in at least 3 images. The photographic sampling season for Eubalaena

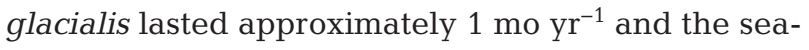
son for E. australis lasted 4 mo. Since growth in body length of adult whales is assumed to have been negligible during the sampling season in any given year, length measurements from all images of an individual whale within that year were combined to calculate the CVs for total length. However, as calves were growing during the season (Best \& Rüther 1992), the CVs for their body length were calculated for each sampling flight. Body width was expected to change during the photographic sampling season for E. australis mothers and calves and between seasons for $E$. glacialis females, so the CVs of the body width data were calculated per flight for $E$. australis mothers and calves and per season for E. glacialis females.

\section{Comparison with girth of carcasses}

Body widths measured at $30 \%$ of the body length from the snout on free-swimming Eubalaena glaci- 
alis were compared with axillary girths measured at necropsy with a Smith-Satterthwaite $t$-test (Devore 1995) to test the hypothesis that body width and diameter are comparable measurements. Statistical significance was determined at $\alpha=0.05$. Girth was measured with a tape measure at the necropsies of 6 relatively fresh carcasses of female $E$. glacialis (Moore et al. 2004, M. J. Moore unpubl. data). Diameter was calculated from girth measurements based on the assumption that the cross-section of a right whale in the region measured is circular; hence, girth was considered as the circumference $(c)$, and diameter $(d)$ was calculated from the equation $c=\pi d$. For those females measured with aerial photogrammetry on multiple occasions, one body width measurement per whale was randomly chosen.

\section{Principal component analysis}

For each photographic sampling season of Eubalaena glacialis and for each flight for E. australis, the mean of the body width measurements was calculated for each measurement site along the body from all images of an individual whale and used as the representative width measurement for that site. Typically morphometric data are normalized for size by using the residuals from regressing the parameter to be examined against size of the individual (Lockyer et al. 1985, Reist 1985, Read 1990, Haug et al. 2002, Perryman \& Lynn 2002). Such regressions were not possible in this study owing to small sample sizes. Body length was correlated with body width at 5 of the 8 measurement sites in E. glacialis, so for principal component analyses (PCAs), widths of E. glacialis were normalized for body length by using width-tolength ratios. Although body width was not correlated with body length in E. australis mothers, the data from both species were combined in the PCAs, requiring the variables to be comparable. As such, width-to-length ratios of E. australis mothers were used only in the PCAs.

The measurement of Eubalaena australis at 2 different times during the fasting phase of lactation, along with the measurement of E. glacialis in the eighth month of lactation (after feeding had resumed), a few months before the start of pregnancy, during late pregnancy, resting and nulliparity, allowed for testing of hypotheses regarding body shape as it relates to stage of lactation and reproductive status. PCA, which offers a simple way to detect patterns in multivariate data that exhibit strong multicollinearity, was used to quantitatively simplify the set of 8 body width measurements from each right whale into 2 variables that best explain the variance in the sets of measurements. The resulting variables, the principal components (PCs), then were used to test the hypotheses. Two PCAs were conducted: one PCA analyzed body width-to-length ratios from $E$. glacialis adult females along with body width-tolength ratios from the July sampling of E. australis mothers, while the other analyzed the same data from the E. glacialis females but combined with body width-to-length ratios from the September-October sampling of the E. australis mothers. Two PCAs were necessary because the data from the E. australis mothers were individual-based and independence would have been compromised within the analysis if both sampling times had been combined into one PCA. Eigenvectors from these 2 PCAs were remarkably similar to those found in preliminary PCAs conducted on the separate data sets (E. glacialis adult females, the July sampling of E. australis mothers, the September-October sampling of the E. australis mothers; see Fig. 2), indicating that combining the data sets from E. glacialis and E. australis did not affect the new variables created by the PCA. Also, 3 E. glacialis individuals were measured in at least 2 stages of reproduction, once during late pregnancy and again after 8 mo of lactating. One of the 3 whales was measured a third time while resting. Independence would have been compromised if all sets of body width data from each reproductive stage of these 3 E. glacialis individuals were included in the PCAs. Yet again, patterns in the eigenvectors were similar to those generated by the above PCAs regardless of which reproductive stage was chosen to represent these 3 whales; consequently, to ensure an adequate sample size of pregnant females, the series of body width-to-length ratios from late pregnancy was used.

The hypothesis that overall body shape is thinner in Eubalaena glacialis that had been lactating for approximately $8 \mathrm{mo}$ than it is for non-pregnant, nonlactating E. glacialis was tested with a 2-sample $t$-test on the PC1 scores from the first PCA. The hypothesis that females in the eighth month of lactation (PC1 scores from lactating E. glacialis) have a thinner overall body shape than do females in the first month of lactation (PC1 scores from E. australis) also was tested with a 2-sample $t$-test on PC1 scores generated from the first PCA. A Bonferroni adjustment was applied to the alpha level to account for multiple tests on the same data, and as such, statistical significance was determined when $\mathrm{p}<0.025$. In addition, a 2-sample $t$-test was used on PC1 scores generated from the sec- 
ond PCA to test the hypothesis that there is no difference in overall body shape between females in the later stage of lactation that had resumed feeding a few months prior (PC1 scores from lactating $E$. glacialis) and females that had been lactating and fasting for a few months (PC1 scores from E. australis).

\section{Changes in body width in individual whales}

Eubalaena australis mothers and calves were measured on more than one occasion, which allowed examination of the body shape of individual whales during the initial months of lactation/suckling, a time during which mothers are fasting and calves are growing at a rapid rate (Best \& Rüther 1992). To test the hypothesis that $E$. australis mothers thinned during this fasting stage of lactation, i.e. that reliance on endogenous nutrient reserves would be apparent in changes in body shape for fasting and lactating $E$. australis, the overall change in body width (width measurements from all sites from all 6 whales combined) of E. australis mothers was compared between the first (July) and third (September) or fourth (October) month of lactation with a paired $t$-test and statistical significance was determined when $\mathrm{p}<0.05$. To assess where along the bodies the changes in body width were occurring, the change in width at each measurement station was compared between the first (July) and third (September) or fourth (October) month of lactation using paired $t$-tests. The Bonferroni adjustment was applied to the alpha level to account for the number of tests and, thus, statistical significance was determined when $\mathrm{p}<0.00625$. Paired $t$ tests also were used to test for a change in body width and in body width-to-length ratios at each measurement site between the first (July) and third (September) month of suckling in E. australis calves. Again, the Bonferroni adjustment was applied to the alpha level to account for the number of tests and statistical significance was determined when $\mathrm{p}<0.00625$.

Three Eubalaena glacialis individuals were measured during late pregnancy and again a year later during late lactation. Paired $t$-tests were used to test for differences in body width at each measurement site along the body between these measurement times. The Bonferroni adjustment was applied to the alpha level to account for the number of tests so statistical significance was determined when $\mathrm{p}<$ 0.00625 .

Statistical analyses were conducted using Matlab v. 7.5.0.342 (R2007b) (The MathWorks) and Systat v. 10.0 (SPSS).
Table 1. Eubalaena australis and E. glacialis. Sample sizes of each life history status measured using aerial photogrammetry. E. australis was photographed in the De Hoop Nature Reserve, South Africa, during July and September or October 1989. E. glacialis was photographed in the Bay of Fundy, Canada, during August 2000, 2001 and 2002

\begin{tabular}{|llc|}
\hline $\begin{array}{l}\text { Species } \\
\text { Age class }\end{array}$ & Life history status & $\mathrm{n}$ \\
\hline E. australis & & \\
Calves & Suckling 1st and 3rd mo & 5 \\
Adult females & Lactating 1st and 3rd mo & 3 \\
& Lactating 1st and 4th mo & 2 \\
& Lactating 1st, 3rd and 4th mo & 1 \\
& Total & 6 \\
E. glacialis & & \\
Adult females & Nulliparous & 4 \\
& Pre-pregnant & 3 \\
& Pregnant & 1 \\
& Pregnant, lactating 8th mo & 2 \\
& Pregnant, lactating 8th mo, resting & 1 \\
& Lactating 8th mo & 9 \\
& Resting & 2 \\
& Total & 22 \\
\hline
\end{tabular}

\section{RESULTS}

Body widths of 22 adult female Eubalaena glacialis were measured (Table 1). Body widths of 6 mother and 5 calf $E$. australis were measured at least twice during the initial months of lactation (Table 1).

The measurement sites at 10 and $20 \%$ of the body length from the snout were located between the snout and the gape of the mouth, i.e. measurements of the width of the heads, while the site $80 \%$ was located on the peduncle of the whales (Fig. 1). The maximum body width measurements occurred at 30 or $40 \%$ of the body length from the snout and ranged from 2.49 to $3.65 \mathrm{~m}$ among adult females (Tables 2 \& 3) (body length ranged from 11.46 to $14.63 \mathrm{~m}$ ) of both species and from 1.02 to $1.76 \mathrm{~m}$ among the Eubalaena australis calves (Table 3) (body length ranged from 4.99 to $8.11 \mathrm{~m}$ ). The minimum measurements always occurred at $80 \%$ of the body length from the snout, and ranged from 0.47 to $1.33 \mathrm{~m}$ in adult females (Tables $2 \& 3$ ) and from 0.27 to $0.46 \mathrm{~m}$ in calves (Table 3).

\section{Precision of estimates}

CVs tended to increase as the size of the measured body part decreased. Mean CVs of body length and body width measured every $10 \%$ of the body length 


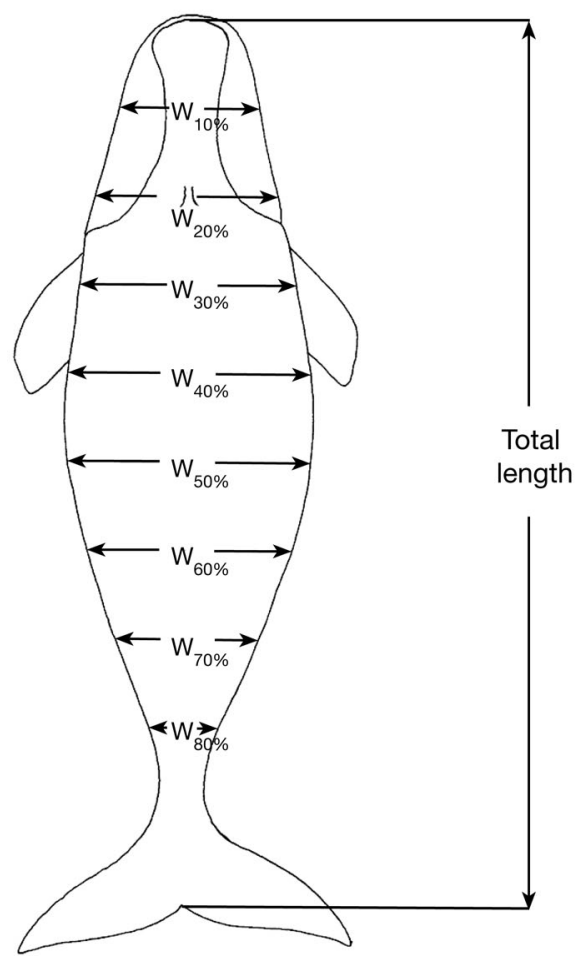

Fig. 1. Eubalaena spp. Diagram of an adult right whale from an overhead perspective showing the features measured using photogrammetry. Body width, $\mathrm{W}_{\mathrm{x} \%}$ (distance between the lateral edges of the whale's body), was measured at sites located every $10 \%$ of the whale's length from snout to fluke notch. Diagram represents stylistic right whale that accurately shows locations of measurement sites but is drawn without regard to nutritional status at any particular life history stage

from the snout on Eubalaena australis mothers and calves and on E. glacialis adult females that were measured in at least 3 photographs are presented in Table 4. Mean CVs ranged from 0.021 (length) to 0.117 (width at $80 \%$ ) for $E$. australis calves, from 0.017 (length) to 0.098 (width at $70 \%$ ) for E. australis mothers, and from 0.013 (length) to 0.087 (width at $80 \%$ ) for E. glacialis adult females.

\section{Comparison with girth of carcasses}

In adult female Eubalaena glacialis, there was no difference in body width measured at $30 \%$ of the body length from the snout of free-swimming whales (mean $\pm \mathrm{SD}=3.01 \pm 0.21 \mathrm{~m}, \mathrm{n}=22$ ) and diameter derived from axillary girth measured on carcasses $(2.80 \pm 0.27 \mathrm{~m}, \mathrm{n}=6)$ (Smith-Satterthwaite $t$-test: $t=$ $1.8164, \mathrm{df}=7, \mathrm{p}=0.11$ ). Also, there was no difference in body length (snout to fluke notch) between the same free-swimming whales $(13.27 \pm 0.67 \mathrm{~m})$ and carcasses $(13.08 \pm 1.17 \mathrm{~m})$ (Smith-Satterthwaite $t$ test: $t=0.3726, \mathrm{df}=6, \mathrm{p}=0.72$ ).

Table 2. Eubalaena glacialis. Descriptive statistics for aerial photogrammetric measurements of body width at each measurement site (every $10 \%$ of the body length [BL] from the snout) for adults measured at different stages of the female reproductive cycle, Bay of Fundy, Canada, during August 2000, 2001 and 2002

\begin{tabular}{|c|c|c|c|c|c|}
\hline \multirow{2}{*}{$\begin{array}{l}\text { Life history } \\
\text { status }\end{array}$} & \multirow{2}{*}{$\begin{array}{l}\text { Measurement } \\
\text { site (\% BL } \\
\text { from snout) }\end{array}$} & \multicolumn{4}{|c|}{-Body width } \\
\hline & & $\begin{array}{c}\text { Mean } \\
(\mathrm{m})\end{array}$ & $\mathrm{SD}$ & $\begin{array}{c}\text { Min. } \\
(\mathrm{m})\end{array}$ & $\begin{array}{c}\text { Max. } \\
\text { (m) }\end{array}$ \\
\hline \multicolumn{6}{|c|}{ Nulliparous adult females } \\
\hline \multirow[t]{8}{*}{$(\mathrm{n}=4)$} & 10 & 2.13 & 0.12 & 1.97 & 2.23 \\
\hline & 20 & 2.72 & 0.20 & 2.44 & 2.87 \\
\hline & 30 & 3.22 & 0.22 & 3.06 & 3.53 \\
\hline & 40 & 3.13 & 0.40 & 2.81 & 3.65 \\
\hline & 50 & 2.97 & 0.36 & 2.59 & 3.40 \\
\hline & 60 & 2.61 & 0.46 & 2.17 & 3.21 \\
\hline & 70 & 1.97 & 0.43 & 1.56 & 2.52 \\
\hline & 80 & 0.98 & 0.28 & 0.75 & 1.33 \\
\hline \multicolumn{6}{|c|}{ Pre-pregnant females } \\
\hline \multirow[t]{8}{*}{$(\mathrm{n}=3)$} & 10 & 2.00 & 0.10 & 1.92 & 2.11 \\
\hline & 20 & 2.56 & 0.13 & 2.47 & 2.71 \\
\hline & 30 & 3.07 & 0.06 & 3.02 & 3.14 \\
\hline & 40 & 3.08 & 0.06 & 3.02 & 3.12 \\
\hline & 50 & 2.90 & 0.05 & 2.87 & 2.96 \\
\hline & 60 & 2.46 & 0.05 & 2.41 & 2.49 \\
\hline & 70 & 1.68 & 0.14 & 1.58 & 1.84 \\
\hline & 80 & 0.89 & 0.04 & 0.86 & 0.93 \\
\hline \multicolumn{6}{|c|}{ Pregnant females } \\
\hline \multirow[t]{8}{*}{$(\mathrm{n}=4)$} & 10 & 2.04 & 0.05 & 1.99 & 2.09 \\
\hline & 20 & 2.59 & 0.11 & 2.52 & 2.76 \\
\hline & 30 & 3.11 & 0.30 & 2.74 & 3.46 \\
\hline & 40 & 3.12 & 0.32 & 2.77 & 3.51 \\
\hline & 50 & 2.98 & 0.30 & 2.65 & 3.37 \\
\hline & 60 & 2.59 & 0.25 & 2.32 & 2.89 \\
\hline & 70 & 1.93 & 0.20 & 1.72 & 2.19 \\
\hline & 80 & 0.94 & 0.10 & 0.81 & 1.03 \\
\hline \multicolumn{6}{|c|}{ Lactating females } \\
\hline \multirow[t]{8}{*}{$(\mathrm{n}=12)$} & 10 & 1.93 & 0.11 & 1.76 & 2.16 \\
\hline & 20 & 2.45 & 0.11 & 2.23 & 2.64 \\
\hline & 30 & 2.86 & 0.17 & 2.66 & 3.13 \\
\hline & 40 & 2.74 & 0.20 & 2.49 & 3.22 \\
\hline & 50 & 2.52 & 0.19 & 2.36 & 2.92 \\
\hline & 60 & 2.17 & 0.19 & 2.01 & 2.59 \\
\hline & 70 & 1.55 & 0.17 & 1.20 & 1.85 \\
\hline & 80 & 0.79 & 0.06 & 0.68 & 0.90 \\
\hline \multicolumn{6}{|c|}{ Resting females } \\
\hline$(\mathrm{n}=3)$ & 10 & 2.00 & 0.13 & 1.86 & 2.11 \\
\hline & 20 & 2.54 & 0.15 & 2.41 & 2.70 \\
\hline & 30 & 3.03 & 0.25 & 2.74 & 3.19 \\
\hline & 40 & 2.96 & 0.37 & 2.55 & 3.27 \\
\hline & 50 & 2.85 & 0.49 & 2.29 & 3.18 \\
\hline & 60 & 2.58 & 0.52 & 1.98 & 2.91 \\
\hline & 70 & 1.93 & 0.30 & 1.58 & 2.14 \\
\hline & 80 & 1.01 & 0.20 & 0.82 & 1.21 \\
\hline
\end{tabular}


Table 3. Eubalaena australis. Descriptive statistics for aerial photogrammetric measurements of body width at each measurement site (every $10 \%$ of the body length [BL] from the snout) for mother and calf measured on 2 occasions during the initial months of lactation and suckling, De Hoop Nature Reserve, South Africa, during July and September or October 1989

\begin{tabular}{|c|c|c|c|c|c|c|c|c|c|}
\hline \multirow{2}{*}{$\begin{array}{l}\text { Life history } \\
\text { status }\end{array}$} & \multirow{2}{*}{$\begin{array}{l}\text { Measurement site } \\
\text { (\% BL from snout) }\end{array}$} & \multicolumn{4}{|c|}{ - Body width $\longrightarrow$} & \multicolumn{4}{|c|}{ Body width } \\
\hline & & Mean $(\mathrm{m})$ & $\mathrm{SD}$ & Min. (m) & Max. (m) & Mean $(\mathrm{m})$ & $\mathrm{SD}$ & Min. (m) & Max. (m) \\
\hline \multicolumn{2}{|c|}{ Suckling calves } & \multicolumn{4}{|c|}{ July } & \multicolumn{4}{|c|}{ September } \\
\hline \multirow[t]{8}{*}{$(\mathrm{n}=5)$} & 10 & 0.68 & 0.05 & 0.65 & 0.77 & 1.01 & 0.05 & 0.92 & 1.07 \\
\hline & 20 & 0.96 & 0.07 & 0.89 & 1.07 & 1.42 & 0.11 & 1.28 & 1.54 \\
\hline & 30 & 1.07 & 0.07 & 1.02 & 1.18 & 1.56 & 0.15 & 1.39 & 1.76 \\
\hline & 40 & 1.05 & 0.10 & 0.96 & 1.21 & 1.48 & 0.14 & 1.28 & 1.65 \\
\hline & 50 & 0.95 & 0.07 & 0.89 & 1.06 & 1.35 & 0.14 & 1.12 & 1.49 \\
\hline & 60 & 0.75 & 0.06 & 0.70 & 0.86 & 1.10 & 0.11 & 0.93 & 1.25 \\
\hline & 70 & 0.52 & 0.04 & 0.47 & 0.58 & 0.74 & 0.06 & 0.63 & 0.79 \\
\hline & 80 & 0.30 & 0.03 & 0.27 & 0.35 & 0.40 & 0.06 & 0.31 & 0.46 \\
\hline \multicolumn{2}{|c|}{ Lactating mothers } & \multicolumn{4}{|c|}{ July } & \multicolumn{4}{|c|}{ September, October } \\
\hline \multirow[t]{8}{*}{$(\mathrm{n}=6)$} & 10 & 1.93 & 0.05 & 1.87 & 2.00 & 1.94 & 0.09 & 1.83 & 2.06 \\
\hline & 20 & 2.57 & 0.15 & 2.43 & 2.84 & 2.49 & 0.16 & 2.33 & 2.76 \\
\hline & 30 & 3.07 & 0.18 & 2.90 & 3.41 & 2.94 & 0.18 & 2.78 & 3.27 \\
\hline & 40 & 3.08 & 0.21 & 2.88 & 3.44 & 2.80 & 0.26 & 2.55 & 3.28 \\
\hline & 50 & 2.89 & 0.26 & 2.67 & 3.35 & 2.60 & 0.24 & 2.42 & 3.04 \\
\hline & 60 & 2.57 & 0.27 & 2.31 & 3.00 & 2.22 & 0.25 & 2.02 & 2.66 \\
\hline & 70 & 1.87 & 0.25 & 1.54 & 2.20 & 1.54 & 0.25 & 1.23 & 1.95 \\
\hline & 80 & 0.98 & 0.19 & 0.69 & 1.16 & 0.69 & 0.14 & 0.47 & 0.90 \\
\hline
\end{tabular}

Table 4. Eubalaena australis and E. glacialis. Mean of coefficients of variation of body length (BL) measurements and of body width (BW) measured every $10 \%$ of the BL from the snout from randomly selected mother and calf E. australis and adult female E. glacialis that were measured in at least 3 photographs. Measurements were made using aerial photogrammetry. E. australis was photographed in the De Hoop Nature Reserve, South Africa, during July, September or October 1989; E. glacialis was photographed in the Bay of Fundy, Canada, during August 2000, 2001 and 2002

\begin{tabular}{|c|c|c|c|c|c|c|c|c|c|c|c|}
\hline \multirow{2}{*}{ Species } & \multirow{2}{*}{ Age class } & \multirow{2}{*}{$\begin{array}{l}\text { No. of sets } \\
\text { of } 3 \text { images }\end{array}$} & \multirow[t]{2}{*}{$\mathrm{BL}$} & \multicolumn{8}{|c|}{ - BW measurement site ( $\%$ BL from snout) } \\
\hline & & & & 10 & 20 & 30 & 40 & 50 & 60 & 70 & 80 \\
\hline E. australis & Calves & 8 & 0.021 & 0.042 & 0.030 & 0.037 & 0.041 & 0.043 & 0.051 & 0.077 & 0.117 \\
\hline E. australis & Mothers & 9 & 0.017 & 0.029 & 0.032 & 0.033 & 0.041 & 0.041 & 0.046 & 0.098 & 0.074 \\
\hline E. glacialis & Adult females & 14 & 0.013 & 0.033 & 0.035 & 0.027 & 0.032 & 0.030 & 0.035 & 0.053 & 0.087 \\
\hline
\end{tabular}

The range of body widths measured from 30 to $40 \%$ of the body length from the snout on adult female Eubalaena glacialis (2.35 to $3.65 \mathrm{~m}, \mathrm{n}=22$ ) and adult female E. australis (2.55 to $3.44 \mathrm{~m}, \mathrm{n}=6$ ) overlapped the range of diameters calculated from axillary and maximum girth measured on carcasses of adult female E. glacialis (2.59 to $3.18 \mathrm{~m}, \mathrm{n}=6$ ) (Table 5). The range of diameters calculated from girth measured at the anterior insertion of the flipper on E. japonica carcasses (2.07 to $4.60 \mathrm{~m}, \mathrm{n}=10$, Omura et al. 1969) and the range of depths of body measured at the same location on the E. japonica carcasses (2.00 to $4.20 \mathrm{~m}, \mathrm{n}=10$, Omura et al. 1969) overlapped but were wider than the ranges of body widths measured from the free-swimming E. glacialis and E. australis (Table 5). The width at $30 \%$ of the body length from the snout of one E. glacialis female
(E. glacialis no. 1004) measured with aerial photogrammetry while free-swimming in August 2002, a few months prior to conception, was $4 \mathrm{~cm}$ different than the diameter calculated from axillary girth measured at necropsy on her fresh carcass in February 2004, during late pregnancy (Table 5).

\section{Principal component analysis}

The PCA on the body width data from adult female Eubalaena glacialis combined with the body width data from the July sampling of the E. australis mothers indicated that PC1 accounted for $86.3 \%$ and PC2 accounted for $5.6 \%$ for a total of $91.9 \%$ of the variability in the data. The PCA on the width data from adult female E. glacialis combined with the later 


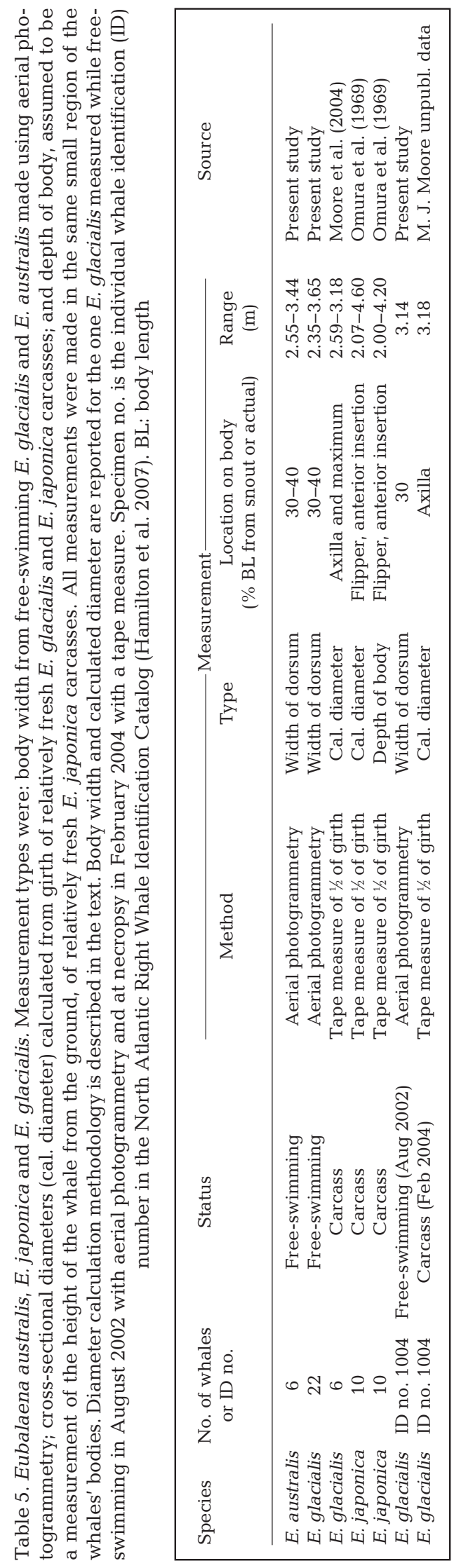

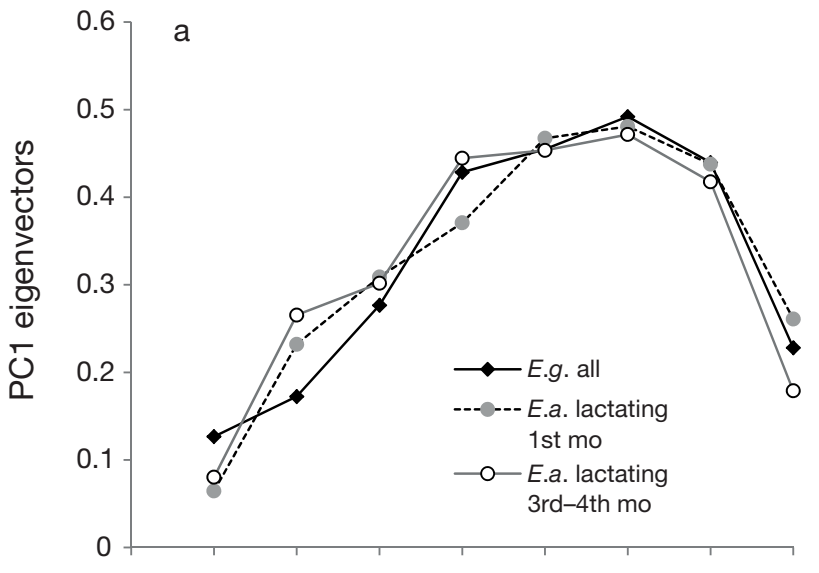



Fig. 2. Eubalaena glacialis and E. australis. Eigenvectors of principal components (a) PC1 and (b) PC2 resulting from the PCA conducted on body width measured using aerial photogrammetry at $10 \%$ intervals of the body length (BL) from the snout of 22 E. glacialis (E.g.) adult females, and 6 E. australis (E.a.) mothers from the initial (July) and later sampling (September, October). E. glacialis was photographed in the Bay of Fundy, Canada, during August 2000, 2001 and 2002; E. australis was photographed in the De Hoop Nature Reserve, South Africa, 1989

sampling of the E. australis mothers indicated that PC1 accounted for $87.9 \%$ and PC2 accounted for $4.6 \%$ for a total of $92.5 \%$ of the variability in the data.

The patterns in the eigenvectors of PC1 for both Eubalaena glacialis adult females and E. australis mothers (each sampling time shown) were similar (Fig. 2a). PC1 eigenvector values were all positive and steadily increased from the lowest values at $10 \%$ of the body length from the snout to the highest values between 40 to $70 \%$ of the body length from the snout; in particular the maximum values occurred at $60 \%$ of the body length from the snout and sharply decreased at $80 \%$. The patterns in the eigenvectors of PC2 for both E. glacialis adult females and E. australis mothers also were similar (Fig. 2b). For $E$. 
$\diamond \quad$ E.g. lactating, 8th mo

$\Delta$ E.g. nulliparous

- E.g. pre-pregnant

+ E.g. pregnant

* E.g. resting

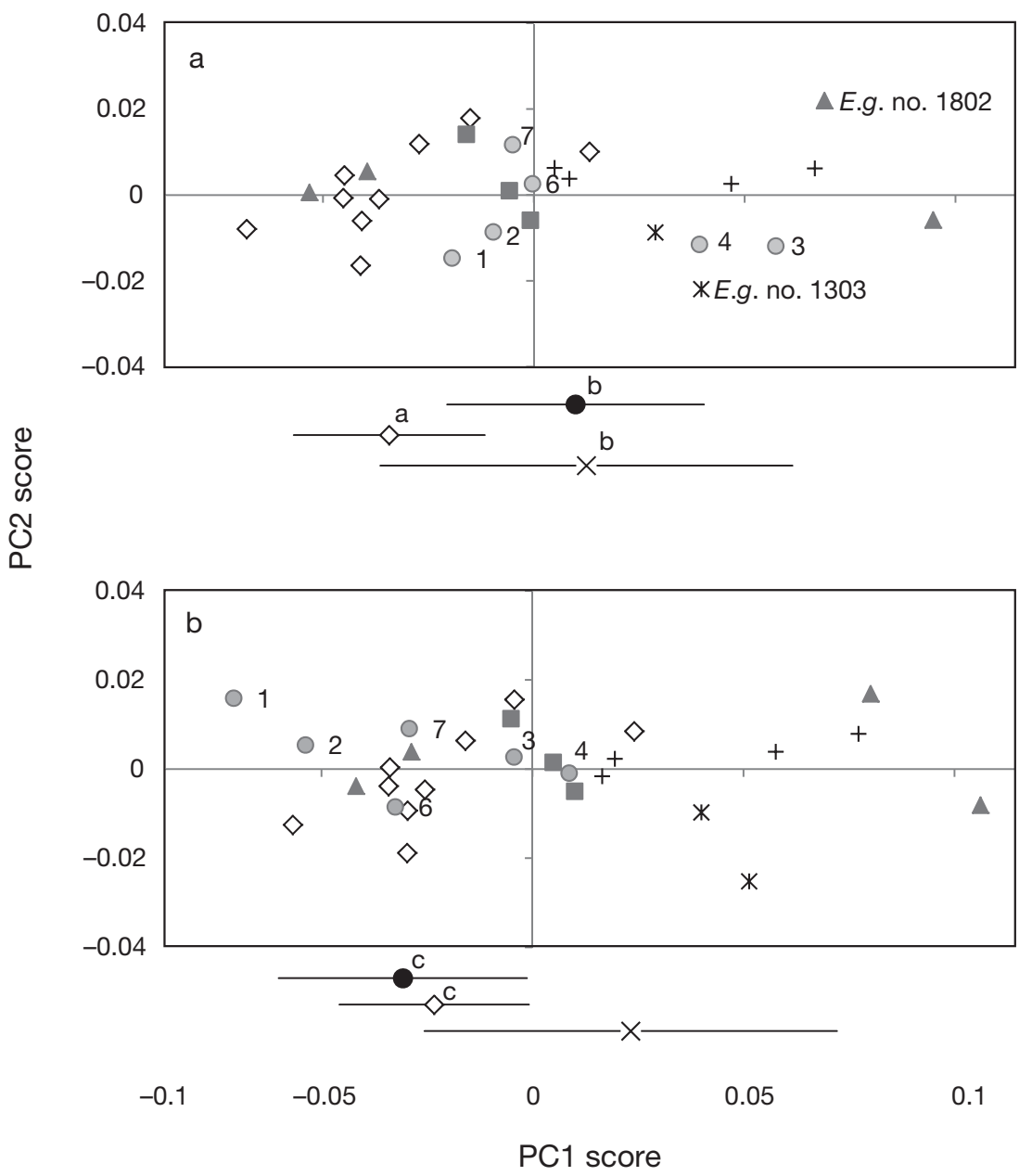

Fig. 3. Eubalaena glacialis and E. australis. Principal components (PC) scores for PC1 and PC2 generated from PCAs conducted on aerial photogrammetric measurements of right whale body width-to-length ratios collected at $10 \%$ intervals of the body length from the snout. E. glacialis (E.g.) was photographed in the Bay of Fundy, Canada, during August 2000, 2001 and 2002; E. australis (E.a.) was photographed in the De Hoop Nature Reserve, South Africa, 1989. (a) PC1 and PC2 scores for adult female E. glacialis of differing reproductive status and for $E$. australis mothers measured in July (the first month of lactation). Each E. australis mother is labeled with a number $(1-4,6,7) ; 2$ E. glacialis females are labeled with their individual whale identification numbers from the North Atlantic Right Whale Identification Catalog (Hamilton et al. 2007). (b) PC1 and PC2 scores from the same series of body width-to-length ratios from the adult female $E$. glacialis combined with the series from the later sampling (SeptemberOctober, third to fourth month of lactation) of the same E. australis mothers. The E. australis mothers are labeled with the same numbers assigned to them in (a). Mean \pm SD of PC1 scores for lactating and non-pregnant, nonlactating E. glacialis and for the E. australis mothers are shown below the panel in both (a) and (b); means with the same letter are not significantly different at (a) $\alpha=0.025$ or (b) $\alpha=0.05$ glacialis adult females, the PC2 eigenvector values were positive on the cranial half of the body (measurement sites 10 to $40 \%$ of the body length from the snout) and negative on the caudal half of the body (measurement sites 60 to $80 \%$ of the body length from the snout). For the initial (July) sampling of E. australis mothers, PC2 eigenvector values were close to zero at measurement sites 10 and $20 \%$ of the body length from the snout, positive at 30 to $60 \%$ of the body length from the snout and negative at 70 and $80 \%$ of the body length from the snout. For the later (September, October) sampling of the E. australis mothers, the PC2 eigenvector values were positive on the cranial half of the body (measurement sites 10 to $40 \%$ of the body length from the snout) and negative on the caudal half of the body (measurement sites 60 to $80 \%$ of the body length from the snout). The similarity in the patterns of eigenvectors demonstrated that females have the same pattern of variability between individuals despite the differences in species and reproductive status, and therefore could be analyzed together.

In Eubalaena glacialis, the mean of the PC1 scores from lactating females $($ mean $\pm \mathrm{SD}=-0.034 \pm 0.023, \mathrm{n}=9$ ) was significantly less than the mean of the PC1 scores from the females of the other, non-pregnant, non-lactating, reproductive stages combined $(0.0130 \pm 0.049, \mathrm{n}=9)$ (two-sample $t$ test: $t=-2.6037$, df $=11, \mathrm{p}=0.012$; Fig. 3a). The E. australis mothers that were measured in the first month of lactation (July) clustered with the non-pregnant, non-lactating, E. glacialis females and had significantly higher PC1 scores (0.0104 \pm 0.031, $\mathrm{n}=6)$ than the lactating E. glacialis females $(-0.034 \pm 0.023, \mathrm{n}=9)$ (2sample $t$-test: $t=-3.23, \mathrm{df}=13, \mathrm{p}=$ 0.003 ; Fig. 3a). When the same $E$. australis mothers were re-sampled in the third and fourth months of lactation and were reanalyzed with the $E$. 
glacialis females in the second PCA, the E. australis mothers clustered with the lactating E. glacialis females and no difference in PC1 scores was found between these 2 groups (2-sample $t$-test: $t=0.556$, $\mathrm{df}=13, \mathrm{p}=0.588$, Fig. 3b). There were no differences among the PC2 scores.

\section{Changes in body width in individual whales}

Lactating Eubalaena australis mothers became thinner between the initial sampling in July and the subsequent sampling in September or October (average change in overall body width $=21.8 \pm 6.1 \mathrm{~cm}$, $\mathrm{n}=6$; paired $t$-test: $t=8.70, \mathrm{df}=5, \mathrm{p}=0.0002$ ), and significant changes in body width occurred at measurement sites 30 to $60 \%$ and $80 \%$ of the body length from the snout (paired $t$-tests: $p<0.00625$; Table 6 , Fig. 4a).

Body width increased significantly at all measurement sites along the bodies of 5 Eubalaena australis calves between the initial measurements (July) and the subsequent measurements (September) (paired $t$-tests: $\mathrm{p}<0.00625$; Table 6, Fig. 5a). In the same

Table 6. Eubalaena australis and E. glacialis. Statistics generated from the paired $t$-tests used to compare mean body width and/or body width-to-length ratios measured using aerial photogrammetry at each measurement point between the first (July) and third (September) or fourth (October) month of lactation or suckling in E. australis mothers and calves photographed in the De Hoop Nature Reserve, South Africa, 1989, and between late pregnancy and late lactation in adult female E. glacialis photographed in the Bay of Fundy, Canada, 2000, 2001 and 2002. ${ }^{*}$ p < 0.00625. BL: body length; BW: body width

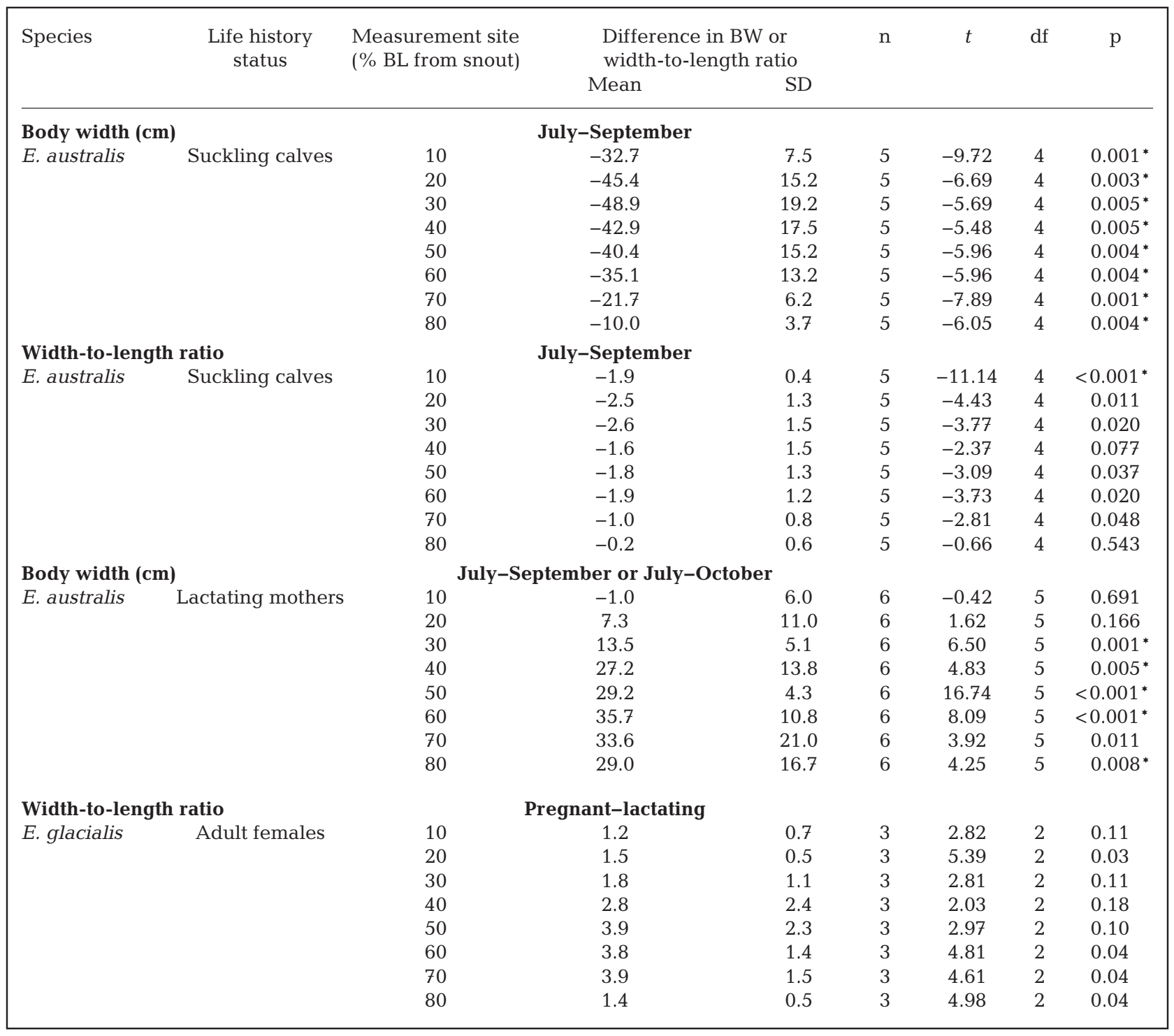



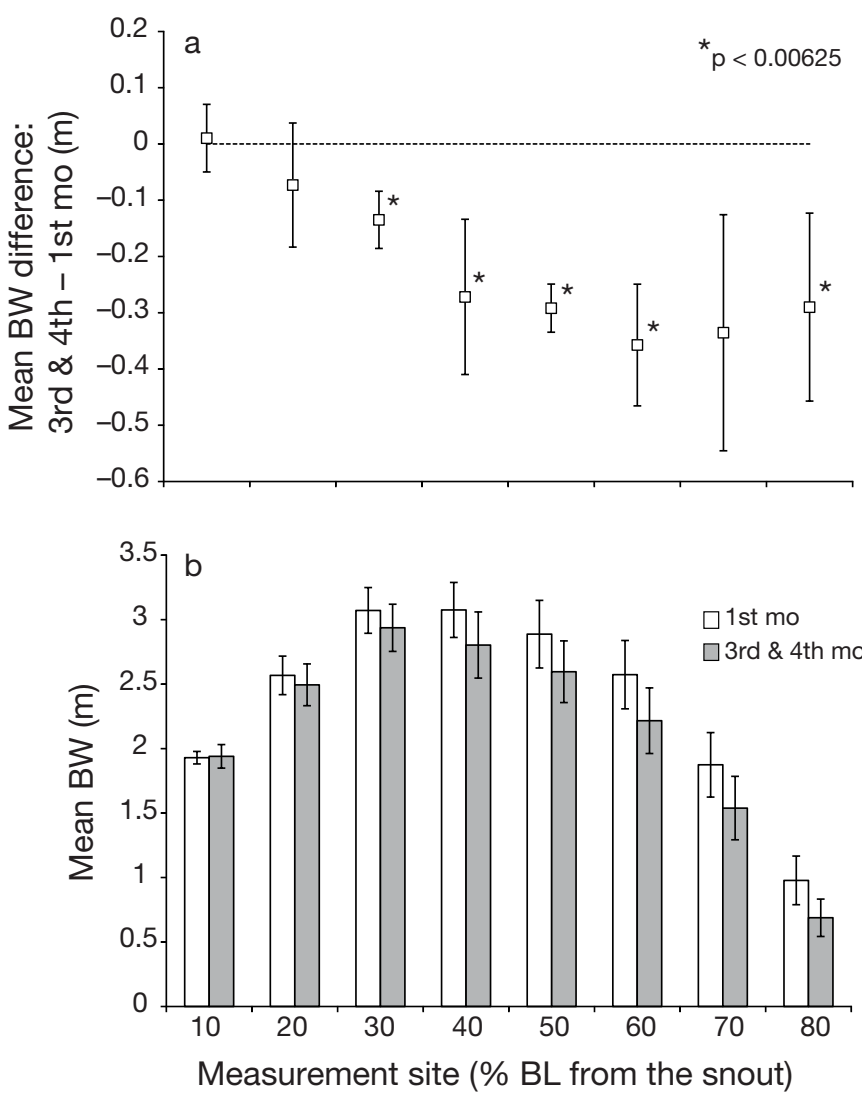

Fig. 4. Eubalaena australis. Comparison of body width (BW) measured every $10 \%$ of the body length (BL) from the snout using aerial photogrammetry on 6 E. australis mothers between the first (July) and third or fourth (September, October) month of lactation, De Hoop Nature Reserve, South Africa, 1989. (a) Mean \pm SD difference in BW (m). Asterisks $(*)$ indicate that the mean difference is significantly different from zero $(\mathrm{p}<0.00625)$. (b) Mean \pm SD BW (m)

calves, the increases in width-to-length ratios between the initial measurements (July) and the subsequent measurements (September) were statistically significant only at the $10 \%$ measurement site (paired $t$-tests: $\mathrm{p}<0.00625$; Table 6, Fig. 5b).

The decrease in width was not statistically significant between late pregnancy and late lactation in the 3 Eubalaena glacialis females (paired $t$-tests: $\mathrm{p}>$ 0.00625 ; Table 6 ). When visualizing the body width change individually, width decreased between late pregnancy and late lactation at all but one measurement site in one of the $3 \mathrm{E}$. glacialis females (no. 1123, Fig. 6a). In the other 2 females, the decrease in body width between late pregnancy and late lactation occurred at limited sites: for whale no. 2145, the width decrease was greatest at sites 50,60 and $70 \%$ of the body length from the snout (Fig. 6b), while for no. 1611, the body width decrease was apparent at all sites except 30 and $70 \%$ of the body length from the snout (Fig. 6c). Whale no. 1611 also was measured after $8 \mathrm{mo}$ of resting during which little change in body width was apparent since late lactation.

\section{DISCUSSION}

Aerial photogrammetry was used to quantify changes in dorsal body shape of free-swimming right whales throughout the female reproductive cycle and during calf growth. Differences in body width were detected at multiple locations along the body between lactating and non-lactating females. A significant decrease in body width during the initial months of lactation in Eubalaena australis mothers also was detected at multiple locations along the body. Finally, increases in width along the body were detected in the calves during the initial months of suckling. These results provide insight into the patterns of changes in nutritive condition that occur with reproduction and growth through the examination of body shape in species that are relatively inaccessible for traditional methods of measuring nutritive condition. In this way, the study introduces a quantitative and non-invasive examination of body shape as a proxy for nutritive condition of free-swimming whales.

\section{Precision and validation of aerial photogrammetric measurements of body width}

The CVs (Table 4) increased as the size of the dimension being measured decreased, which is similar to the trend observed by Best \& Rüther (1992) and Perryman \& Lynn (2002). Best \& Rüther (1992) suggested that such a trend implies a uniform error in endpoint detection irrespective of the distance between the points, so that relative error increases with decreasing measurement distance. The CVs are consistent with those reported in other large whale photogrammetric studies (Cubbage \& Calambokidis 1987, Best \& Rüther 1992, Koski et al. 1992, Perryman \& Lynn 2002), except that the CVs of the width measurements from the caudal measurement sites (sites $60 \%, 70 \%$, and $80 \%$ ) on adults and from all measurement sites on the calves are slightly higher, probably because the dimensions being measured were smaller.

Body fat and nutritive condition of cetaceans is often assessed on carcasses with measurements of body girth (e.g. Lockyer et al. 1985, Lockyer 1986, 

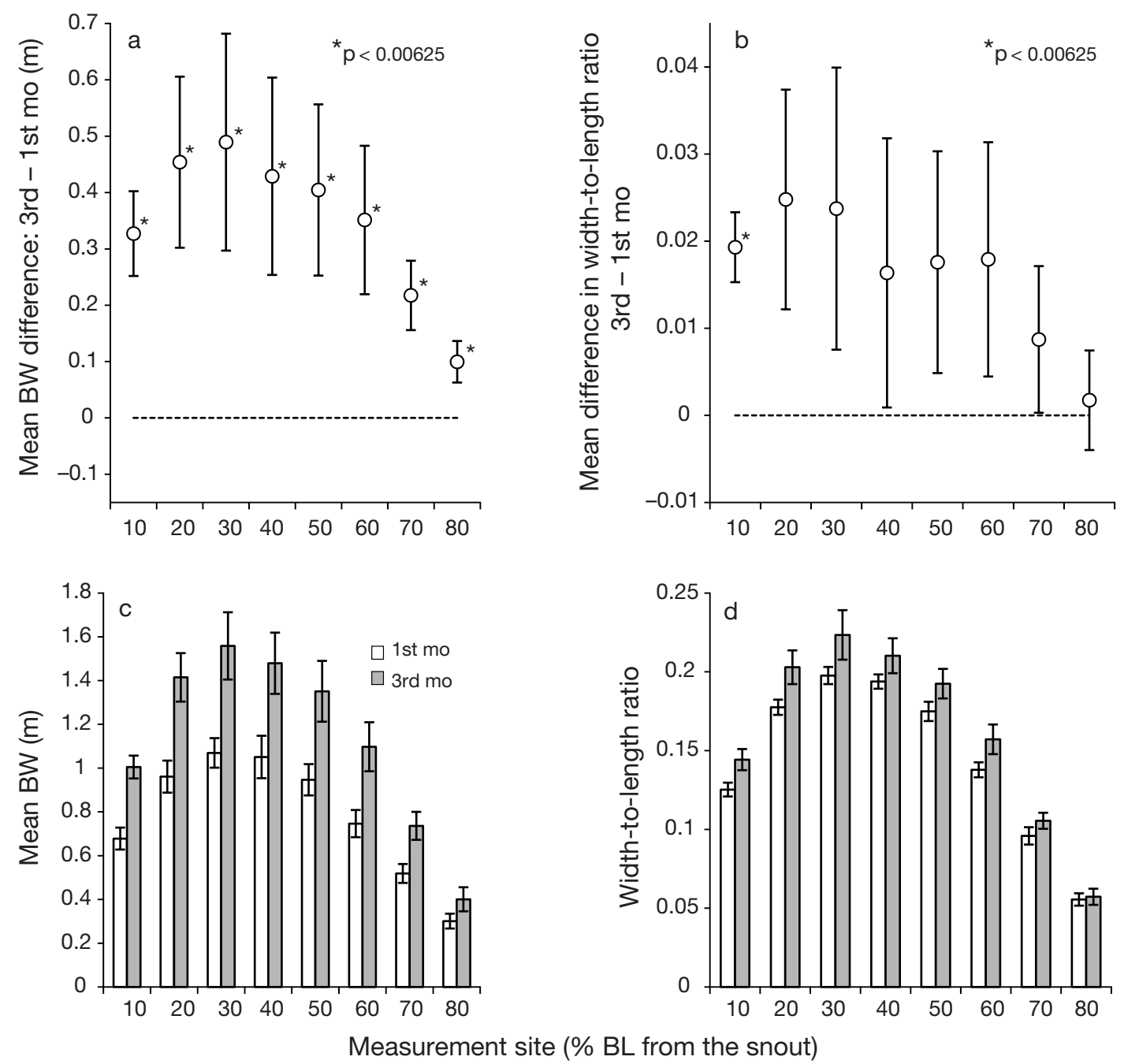

Fig. 5. Eubalaena australis. Comparison of body width (BW) measured every $10 \%$ of the body length (BL) from the snout using aerial photogrammetry on 5 calves between the first (July) and third (September) month of suckling, De Hoop Nature Reserve, South Africa, 1989. Mean \pm SD in (a) difference in BW (m), (b) difference in body width-to-length ratios, (c) BW (m) and (d) body width-to-length ratios. Asterisks ( $*$ ) indicate that the mean difference is significantly different from zero ( $p<0.00625)$

1987, Read 1990, Ichii et al. 1998, Haug et al. 2002). To explore how the photogrammetric measurements of body width of free-swimming whales related to measurements of girth of whale carcasses, it was assumed that the cross-section of a right whale is circular in the region measured, 30 to $40 \%$ of the body length from the snout, as has been assumed in other large whale studies (e.g. Lockyer et al. 1985, Bose \& Lien 1989, Woodward et al. 2006). Underwater measurements of a captive gray whale calf suggested that the assumption of a circular cross-section at the location of maximum girth is valid (Sumich et al. 2001). Thus, girth was considered the circumference of a circle and diameters were calculated accordingly. The range of diameters calculated from girths of Eubalaena japonica (Omura et al. 1969) over- lapped but was wider than the range of body width measurements collected from the free-swimming $E$. australis and E. glacialis (Table 5), probably because the body lengths of the E. japonica were longer than any individuals of the other 2 species measured in the present and other studies (Best \& Rüther 1992, Moore et al. 2004, W. L. Perryman unpubl. data). The ranges of diameters calculated from the girths of relatively fresh carcasses of E. glacialis were similar to the ranges of body width measured from the freeswimming E. glacialis and E. australis (Table 5). For E. glacialis adult females, body width measured at $30 \%$ of the body length from the snout of freeswimming whales was not statistically different from the diameter derived from axillary girth measured on carcasses (body length of the 2 groups did not differ) 

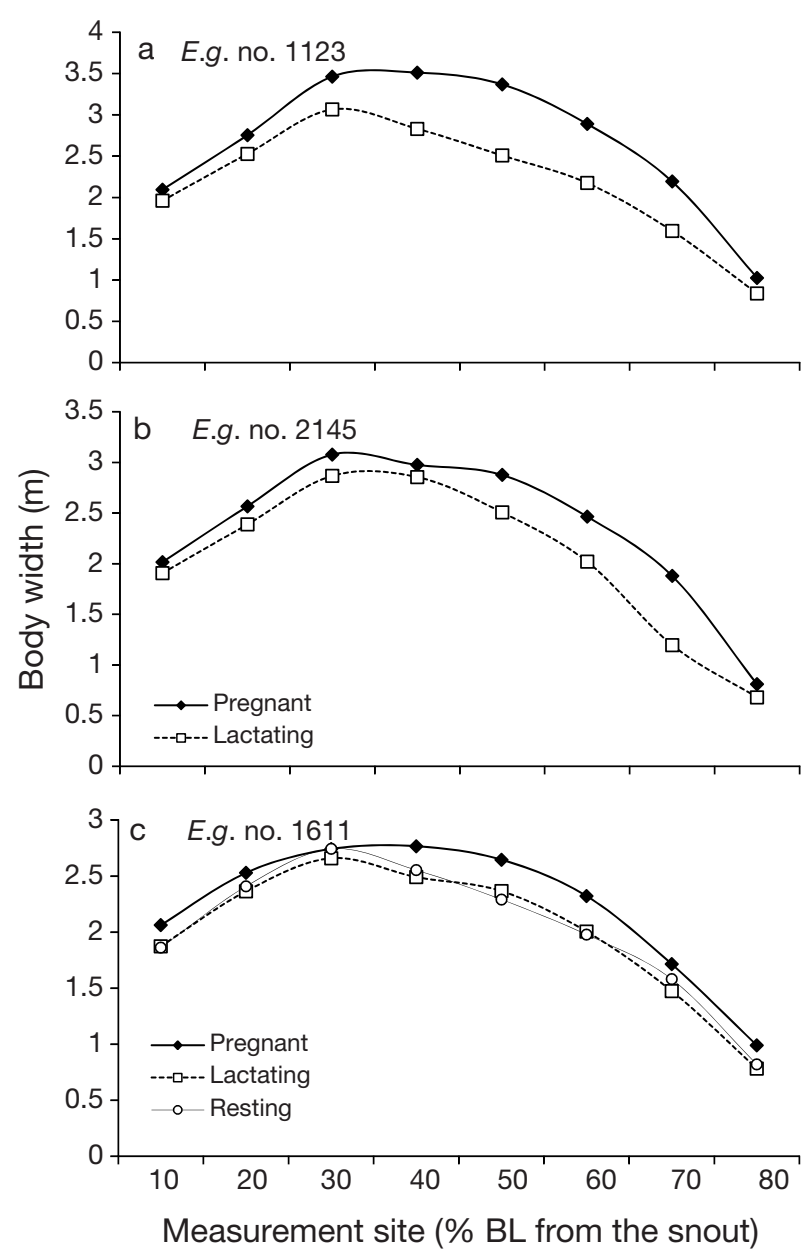

Fig. 6. Eubalaena glacialis. Body width measured every $10 \%$ of the body length (BL) from the snout using aerial photogrammetry on 3 females sampled in multiple years at different stages of the reproductive cycle, Bay of Fundy, Canada, August 2000, 2001 and 2002. E. glacialis (E.g.) numbers refer to individual whale identification numbers in the North Atlantic Right Whale Identification Catalog (Hamilton et al. 2007)

(see 'Results'). Of particular note, one E. glacialis female was measured with both methods with only a $4 \mathrm{~cm}$ difference at this site along the body of low variability among reproductive states: the photogrammetric measurement of width at $30 \%$ of the body length from the snout in August 2002, a few months prior to conception, was $3.14 \mathrm{~m}$, and the diameter derived from the axillary girth of her carcass in February 2004, during late pregnancy, was $3.18 \mathrm{~m}$ (M. J. Moore unpubl. data). Given the overlap of ranges and the statistical similarity between body width measurements from free-swimming right whales and diameters derived from girths of right whale carcasses, we conclude that body width and diameter are comparable dimensions.

\section{Interpreting dorsal body shape from 8 body width measurements}

The PCAs demonstrated that although 8 measurements of width were made along the bodies of right whales; the dimensionality of the data was most apparent in 2 variables. PC1 accounted for 86.3 and $87.9 \%$ of the variability in the data while PC2 accounted for 5.6 and $4.6 \%$. Together, the other 6 PCs, generated by the PCAs accounted for the remaining 7.5 and $8.1 \%$ of the variability in the data and were not considered to be important to the interpretation of the analyses.

The elements of an eigenvector describe the relative contribution of the original variables to a principal component and can be used to characterize patterns in the data. Patterns in the eigenvectors generated from the PCAs were remarkably similar despite the differences in the combinations of data analyzed (Fig. 2). Such similarity in the patterns of the eigenvectors indicated consistency in the variability of right whale body shape across different stages of reproduction and between right whale species. The eigenvectors demonstrated that PC1 represented overall width of the body shape between 40 and $70 \%$ of the body length from the snout. Moreover, the PC1 eigenvector indicated that the greatest variability in body width among females of differing reproductive stages occurred at $60 \%$ of the body length from the snout. The PC1 eigenvector elements at 10 and $20 \%$ of the body length from the snout were small because this region of the body comprises the skull and jaw (see Fig. 1), the bony structure of which limits variability in width. The PC2 eigenvector for both Eubalaena glacialis and E. australis showed positive values at the cranial or midsection measurement sites and negative values at the caudal measurement sites (Fig. 2). Whales with high positive PC2 scores had longer residual widths at the cranial or midsection sites, than at the caudal points; hence, PC2 represented cranial or midsection width relative to the caudal portion of the whale. We do not attach much meaning to the slight difference in the E. australis patterns because the sample size is small, the amount of variability accounted for by PC2 is small and both patterns indicate a contrast between cranial and caudal measurements. When the scores of PC1 and PC2 were plotted together (Fig. 3), there was a greater spread in the PC1 scores than in the PC2 scores, as expected from the high percentage of variability captured by PC1, suggesting that reproductive status of mature females affects the overall corpulence of the body, in terms of width from 40 to $70 \%$ 
(particularly at $60 \%$ ) of the body length from the snout, more than it affects body width of the midsection of the body relative to the caudal region.

\section{Body shape and the reproductive cycle}

Lactation was estimated to be the costliest part of the female reproductive cycle in baleen whales (Lockyer 1981). During their stay in the calving habitats, the calves need to grow to a large enough size and gain enough weight to be able to survive the migration to and the stay in the colder, more productive waters of the feeding grounds. Eubalaena australis calves grow in body length at a rate of $2.8 \pm$ $0.7 \mathrm{~cm} \mathrm{~d}^{-1}$ while in the calving habitats (Best \& Rüther 1992); we assume the growth rate of E. glacialis calves to be similar during this time. This initial stage of rapid growth is supported solely by milk produced by the mother. However, there is no evidence that the mothers feed while in the calving habitats, and as such, must rely on endogenous reserves to support the metabolic requirements of their calves and themselves during the initial months of lactation. Mean and maximum residence times in the nursery waters for mothers and calves were reported for several $E$. australis populations (mean $\pm \mathrm{SD}$, maximum): Australia $=70.9 \pm 30,108 \mathrm{~d}$ (Burnell \& Bryden 1997); Argentina $=77 \pm 36,170 \mathrm{~d}$ (Rowntree et al. 2001); South Africa $=59 \pm 3.9,105 \mathrm{~d}$ (although this mean is probably underestimated owing to subsequent sightings outside of the study area; Best 2000). The 6 mothers measured in more than 1 mo here were part of the Best (2000) analysis; their mean residence times in the study area was $69.5 \pm 9.3 \mathrm{~d}$ (range $=61$ to 78 d). For the 2000 to 2003 calving seasons, E. glacialis mother-calf pairs spent an average of $50 \pm 20 \mathrm{~d}$ (range $=14$ to $96 \mathrm{~d}$ ) in the calving habitat (Right Whale Consortium 2011). Moreover, feeding probably does not resume until mother right whales arrive in the feeding habitats after migration from the calving habitats. Firestone et al. (2008) estimated an average travel time of 21 to $24 \mathrm{~d}$ from the calving waters to the tip of Long Island, USA, for E. glacialis, while Mate et al. (2011) describe concerted movement southward from the South African coast for $5 E$. australis that lasted from 9 to $22 \mathrm{~d}$. Therefore, for 2 to $5 \mathrm{mo}$, the source of sustenance for mother and calf right whales is the mother's endogenous nutrient reserves.

Since Eubalaena glacialis mothers are thought to wean their calves after 10 to 12 mo of lactation (Hamilton et al. 1995, Hamilton \& Cooper 2010), the measurements from E. glacialis mothers in the present study were considered to have been collected during late lactation. The PC1 scores from lactating E. glacialis were significantly lower than those of non-lactating, non-pregnant females, indicating that females that are in the later stages of lactation had the thinnest overall dorsal body shape among adult female E. glacialis (Fig. 3). Similarly, girth of fin whales Balaenoptera physalus in the later stages of lactation was thinner than that of other adults (Lockyer 1987).

The calving season of the South African Eubalaena australis population extends from late June to late October (Best 1994). The initial photographic sampling of the 6 E. australis mothers was collected at the end of July and is therefore considered to have occurred during the initial weeks of lactation. The PC1 scores from this initial sampling clustered with the non-lactating E. glacialis females and were significantly greater than the PC1 scores of the $E$. glacialis females that had been lactating for approximately 8 mo (Fig. 3a). The subsequent measurements of the E. australis mothers were collected at the end of September or in mid-October and therefore considered to be measurements of the females after 2 to 4 mo of lactation. The PC1 scores from this second sampling clustered with and were not significantly different from those of the E. glacialis females that had been lactating for approximately 8 mo (Fig. 3b). The shift along the PC1 axis in the scores for the $E$. australis mothers from clustering with non-lactating E. glacialis females to clustering with E. glacialis females that were in the eighth month of lactation suggests 1 of 3 scenarios: (1) the body width of female right whales reaches a minimum by 2 to 4 mo of lactation and stays that size after transitioning to the feeding stage of lactation, (2) the body width of female right whales becomes further reduced before they resume feeding and subsequently increases slightly during the months after feeding resumes or (3) the body shape of the 2 species does not change the same way over the course of lactation, which is unlikely given the overlap of PC scores (Fig. 3) and the similarity in the patterns of the eigenvectors between the 2 species (Fig. 2). Without monthly sampling throughout the entire duration of lactation, it will be difficult to determine which of these scenarios is occurring. Nevertheless, the shift along the PC1 axis confirms that body shape of mother right whales thinned during the initial months of lactation. This thinning also was observed in data from individual whales: body width significantly decreased at 30 to $60 \%$ and $80 \%$ of the body length from the snout in 
the 6 E. australis mothers measured in the first and again in the third or fourth month of lactation (Fig. 4, Table 6). Furthermore, the wide body shape of $E$. glacialis no. 1303 (Fig. 3a) was interesting given that her sighting record shows that she lost a calf during the previous year's calving season. Thus, the fasting stage of lactation ended early for whale no. 1303 and we did not observe the same thinning associated with lactation that was observed in the other calving females.

The reliance on endogenous nutrient reserves was apparent in body shape changes, particularly during the initial months when mothers are fasting and lactating simultaneously. As such, the initial months of lactation may be the most energetically demanding part of the female right whale's reproductive cycle. One could argue that mid to late lactation would be more demanding since the calf and its energetic demands have grown. However, (1) Eubalaena glacialis calves appear to be feeding on zooplankton prey at approximately 8 mo (Baumgartner \& Mate 2003), and attempts at skim-feeding have been observed as early as 6 mo of age in E. australis (Best 2007), and (2) right whale mothers resume feeding midway through lactation; both of these factors may relieve some of the demand on the female's endogenous reserves. In lactating fin whales, girth (Lockyer 1987) and lipid content of blubber (Aguilar \& Borrell 1990) increased significantly during the summer feeding season, suggesting that despite lactational expenditure, female fin whales in the later stage (the feeding stage) of lactation were able to achieve a positive energy balance. The thinning of body shape observed in individual whales and as indicated by the shift in PC1 scores provides a basis for future studies regarding the energetics, endogenous reserves and stage of lactation in right whales.

The larger variability in PC1 scores for nonlactating Eubalaena glacialis compared with other demographic groups indicated a greater range of overall body widths within that group. Although small sample sizes within reproductive categories precluded conclusive inferences about overall dorsal body shape among non-lactating E. glacialis, there may be distinctive body shapes for certain stages of the female right whale reproductive cycle, as suggested in Fig. 3. As discussed, stage of lactation was apparent in overall body shape (PC1 scores). Also, the 3 pre-pregnant females appeared to group closely together. The 4 pregnant females did not cluster together as closely as the pre-pregnant females, but their PC1 scores were all positive, and PC2 scores, all close to zero, had the least amount of spread among the reproductive stages. If further study confirms that reproductive status can be determined from body shape, then we may be able to gain a better understanding of the high variability in reproduction experienced by E. glacialis, e.g. by detecting pregnancies that either were not detected by routine aerial surveys or that may have ended in spontaneous abortions. For example, this study may have detected an unsuccessful pregnancy for E. glacialis no. 1802 (Fig. 3a). This whale was $12 \mathrm{yr}$ old at the time of measurement and although she was 1 yr older than the average age of first parturition (11.4 yr, Kraus et al. 2007), she had not yet calved. According to the PC scores, the overall body shape of E. glacialis no. 1802 was exceptionally wide (see Fig. 3a) in August 2000. Throughout the following winter calving season (December 2000 through March 2001) she was sighted frequently in the calving habitat but not with a calf. The high PC scores and sighting record for E. glacialis no. 1802 suggest that she may have been pregnant at the time of measurement but that the foetus was subsequently aborted or the calf died at or shortly after birth.

The change in body width in the year between late pregnancy and late lactation was obvious among the 3 Eubalaena glacialis females (Fig. 6). The robust body shape during the later stage of pregnancy thinned noticeably by the time the 3 females were remeasured during the later stage of lactation. The change in reproductive status, along with the lack of more frequent sampling, complicates the interpretation of the observed thinning between late pregnancy and late lactation because part of the decrease in body width can be attributed to the birth of the fetus. However, the significant thinning of the E. australis mothers, both in body shape (present study) and blubber thickness (Miller et al. 2011), between the first (post-partum) and third or fourth month of lactation strongly suggests that changes to nutritive condition during lactation also contributed to the decrease in body width between late pregnancy and late lactation.

One of the 3 Eubalaena glacialis females was measured a third time, 8 mo after weaning, and exhibited little change in body shape after 8 mo of resting (Fig. 6c). Blubber thickness increased with the number of years since last calving in female right whales, suggesting there was a recovery from the energetic costs of lactation (Miller et al. 2011). In the present case, the lack of an increase in overall body shape during the $8 \mathrm{mo}$ of resting could indicate that (1) feeding conditions were inadequate for recovery 
to be measureable and/or (2) recovery was not detectable in measurements of body width after 8 mo.

\section{Body components that may contribute to body shape}

The components that may contribute to variability in body shape include: (1) structural components that can vary with nutritional condition, such as blubber, muscle, liver and visceral fat; (2) compartments that can vary with physiological state, such as blood volume, interstitial and cellular fluid and gastrointestinal ingesta volume; (3) gas, which changes in volume with pressure, digestive state in the intestines and recent respiratory activity in the pulmonary system.

Body fat is an essential endogenous nutrient reserve upon which cetaceans rely during periods of negative energy balance (Rice \& Wolman 1971, Lockyer et al. 1985, Lockyer 1986, 1987, Aguilar \& Borrell 1990, Koopman et al. 2002, Miller et al. 2011). Based on comparative work in other large whale species, the lipid content of visceral fat, muscle and blubber likely contribute to body girth. In fin whales, reductions in girth and blubber thickness were observed in lactating females (Lockyer 1987). Lactating fin whales had the lowest lipid content in blubber among all whales (Aguilar \& Borrell 1990), and 2 lactating fin whales had lower lipid content of blubber, muscle and visceral fat compared with other adult females (Lockyer 1987). In minke whales Balaenoptera acutorostrata, Haug et al. (2002) detected significant increases in girth, and Næess et al. (1998) observed increases in blubber weight and thickness, lipid content of muscle and visceral lipid weight during the summer feeding season. When dorsal body shape and blubber thickness (Miller et al. 2011) were measured on some of the same adult female Eubalaena glacialis during the same sampling seasons, both were significantly thinner in females that were in the later stage of lactation. Corresponding to the significant thinning of body shape observed here, blubber thickness decreased significantly during the initial months of lactation in E. australis found off the coast of South Africa (Miller et al. 2011), which suggests that changes to blubber thickness arising from blubber lipid catabolism contribute to changes in dorsal body shape. However, changes in blubber thickness do not appear to be directly proportional to changes in body girth for fin whales (Lockyer 1986, 1987) and minke whales (Haug et al. 2002), suggesting that changes to other aspects of body composition also contribute to body width and girth.

Protein reserves also are essential to mammals during periods of negative energy balance (Swick \& Benevenga 1977, Robbins 1993). During lactation, 'maternal protein reserves may be catabolized to supply amino acids for milk protein synthesis and gluconeogenesis' (Pine et al. 1994). In lactating dairy cattle, body protein content varied in a similar way to body fat (Belyea et al. 1978). Likewise, in lactating northern elephant seals Mirounga angustirostris, a phocid species that is adapted to abstain from food and water during lactation, the contribution of protein to energy metabolism increased as the proportion of adipose tissue decreased with time from parturition (Crocker et al. 1998). Two other phocid species that fast during lactation, grey seals Halichoerus grypus and hooded seals Cystophora cristata, lost 16 and $7 \%$ of initial protein reserves, respectively, which appeared to be related to milkprotein output (Mellish et al. 1999, Mellish \& Iverson 2001). Based on isotopic measurements of milk production, Oftedal (2000) estimated that 16 to $18 \%$ of maternal body protein is transferred to the offspring via milk in several species of fasting seals and bears. Skeletal muscle is the primary depot of labile protein reserves in rats and cows and significant changes to fiber diameter and cross-sectional area were measured in the longissimus dorsi muscle of cows during changes to their nutritional status (see Swick \& Benevenga 1977 for review). Moreover, protein synthesis in skeletal muscle varies with changes in nutritional status (Swick \& Benevenga 1977). Although confirmatory studies are needed, it is likely that changes to the dimensions of musculature due to protein catabolism contribute to the differences in dorsal body shape observed here.

Further study is necessary to identify the body components that contribute to body girth and width and to determine how these components specifically relate to girth and width measurements. It is possible that respiration may affect measurements of body width, but owing to a low sample size of whales with open blowholes, we were unable to determine the degree of effect. Gastrointestinal ingesta volume probably does not contribute to body width because Haug et al. (2002) found that minke whale girth was not affected by stomach fullness. The extent to which body fluid influences the geometry of a right whale's body is unknown, but Gales \& Renouf (1994) found a significant correlation between surface area of harp seals Phoca groenlandica, calculated from girth measurements of serial cones, and total body water. 
Based on the aforementioned discussion, thickness of the blubber and muscles, possibly the adiposity of the viscera and the presence of a fetus for a late-term pregnant female may be primary determinants of right whale body shape.

\section{Nutritive condition along the body}

The blubber and muscle of the caudal areas of the body appear to be an important site for lipid storage in balaenopterids. In fin whales, blue whales Balaenoptera musculus and minke whales, dorsal muscle samples from caudal to the dorsal fin had the highest lipid content among muscle samples collected from various locations along the body (Feltmann et al. 1948, Lockyer et al. 1984, Næss et al. 1998), and the lipid content of the peduncle musculature increased from anus to flukes (Feltmann et al. 1948). Seasonal increases in the lipid content of the musculature of minke whales, particularly in the dorsal muscles caudal to the dorsal fin, were detected during the summer feeding season (Næess et al. 1998). Corresponding to the seasonal increase in muscle lipids of minke whales there was an increase in blubber thickness at dorsal and lateral sites caudal to the dorsal fin (Næss et al. 1998). Anoestrous female fin whales and sei whales $B$. borealis stored more lipid in the tail muscles than at any other age and reproductive class tested, and blubber thickness was most variable among age and reproductive classes in the caudal dorsal sites (Lockyer et al. 1985). In the 6 Eubalaena australis mothers, the greatest decrease in body width during the first few months of lactation occurred between 40 and $80 \%$ of the body length from the snout (Fig. 4). Furthermore, the results of the PCAs indicated that the greatest variability among female right whales of differing reproductive stages occurred at $60 \%$ of the body length from the snout. Taken together, these results indicate that, like balaenopterids, the caudal portion of the body may be an important area for storage of lipid reserves in right whales. Therefore, $60 \%$ of the body length from the snout may be the best location to measure width when assessing adult right whale nutritive condition.

\section{Body shape and calf growth}

The body width of the Eubalaena australis calves significantly increased over time at all measurement sites along the body during the initial months of suckling (Table 6, Fig. 5a). In contrast to the mothers, significant changes in width were observed at 10 and $20 \%$ of the body length from the snout, indicating significant growth in the head and jaw. Lockyer (1981) observed the most growth activity (in terms of skull width-to-length and girth-to-length ratios) in the heads of juvenile balaenopterids, attributing such expansion to the need for the jaws to accommodate the continuously growing baleen. Also, although only statistically significant at $10 \%$ of the body length from the snout, the change in ratios of body width to length was apparent at sites 10 to $30 \%$ and 50 to $70 \%$ of the body length from the snout between the initial measurements (July) and the subsequent measurements (September) (Table 6, Fig. 5b), suggesting that the right whale calves get wider more rapidly than they get longer. However, the increase in body width-to-length ratios was variable among calves, suggesting differing patterns of growth. The relative growth of caudal girth (depth of tail below the dorsal fin) also was variable between the balaenopterid species and between sexes (Lockyer 1981), but the data appeared to have been collected from older, larger whales than the right whale calves measured in the present study. The increases in body width during the initial months of suckling, in part, can be attributed to increases in blubber thickness; a significant increase in dorsal blubber thickness was detected during the initial months of suckling in freeswimming E. australis calves of this South African population (Miller et al. 2011).

\section{Body shape, hydrodynamics and buoyancy}

According to Woodward et al. (2006), the morphology of right whales is specialized for slow cruising, which is advantageous for their continuous filterfeeding technique. The feeding technique requires a large head, which, in turn, necessitates a rotund body to maintain an optimal streamline. Our results indicated significant changes to body shape associated with changes to reproductive status and nutritional condition. Such changes to body shape almost certainly will affect its hydrodynamics and, hence, swimming efficiency. For example, by using computational fluid dynamic methods Nousek-McGregor (2010) found an increase in locomotor costs for a pregnant right whale resulting in a potential 3 to $4 \%$ increase in viscous drag. If the pregnant female were foraging, she could experience a 24 -fold increase in drag over that calculated for a gliding, traveling, non-pregnant right whale because the drag associ- 
ated with foraging and fluking would be compounded by the increase in viscous drag created by the abdominal distention (Nousek-McGregor 2010).

We propose that changes to lipid and protein in blubber, muscle and viscera associated with nutritional condition contribute to the observed changes in right whale body shape during lactation. Such measureable changes to the composition of the body have the potential to alter whole body buoyancy because the densities of skeletal muscle $\left(1.06 \mathrm{~g} \mathrm{~cm}^{-3}\right.$ for unfixed rabbit and canine muscle, Mendez \& Keys 1960) and lipids (0.93 $\mathrm{g} \mathrm{ml}^{-1}$ for triacylglycerols from marine teleosts, Phleger 1991) differ from the density of seawater (1.024 to $1.026 \mathrm{~g} \mathrm{ml}^{-1}$, Phleger 1991). Dunkin et al. (2010) observed that pregnancy and emaciation influenced the contribution of integument to whole body buoyancy in Atlantic bottlenose dolphins Tursiops truncatus. Any changes to buoyancy could affect energetic cost of locomotion during swimming, diving and feeding. Based on the diving behavior of 8 whales, right whales are thought to be positively buoyant even under hydrostatic pressure (Nowacek et al. 2001). However, whaling data suggest that right whales do not always float when killed (Reeves \& Mitchell 1986); for instance, in one episode of coastal whaling for Eubalaena australis, 9 out of 42 , or $21.4 \%$, of right whales killed sank after death, 2 of which were recorded as 'dry skins' (Best 2006). Differences in blubber thickness appeared to be related to differences in dive behavior for $E$. glacialis (Nousek-McGregor 2010). Therefore, body width measurements may be useful to investigations of the physics and energetics of right whale locomotion and feeding.

\section{SUMMARY AND CONCLUSIONS}

The comparability of body width and diameter suggests that a series of aerial photogrammetric measurements of width along the length of the body could be used to estimate body volume and mass of right whales. Accurate estimations of body volume and morphometric dimensions are important to studies on energetics and hydrodynamics (e.g. Woodward et al. 2006, Nousek-McGregor 2010, see last section in the 'Discussion'). Accurate estimates of body mass also are important for calculating safe dosages of sedative to enhance the removal of lifethreatening gear entanglements (Moore et al. 2010). Furthermore, given the threat of gear entanglements to the population (Moore et al. 2004, Kraus et al. 2005), evaluating nutritional condition by quantify- ing body shape could be used as a clinical tool for establishing prognosis of entangled whales, which is necessary for determining intervention.

Given that body girth and width integrate major structural components that can vary in volume with nutrition, we hypothesize that the overall body width of the dorsal aspect of right whales vary during energetically demanding events and thereby demonstrate that quantification of body shape can be used to assess overall nutritional condition of right whales. PCA indicated that the variability in dorsal body shape was consistent among reproductive stages and between right whale species and that change in reproductive status primarily affected the overall corpulence of the body, particularly during lactation. Thus, lactation, especially the fasting portion, can be considered a substantial energetically demanding time for a female right whale. Rapid growth also can be considered an energetically demanding event; all sites along the bodies of 5 Eubalaena australis calves significantly widened during the initial months of suckling, a time of rapid growth in body length (Best \& Rüther 1992). During these energetically demanding events, dorsal body width was variable at multiple locations along the length of the body. Both the PCAs and the analysis of the longitudinal data indicated that body width was most variable and, hence, may be most indicative of nutritional condition at $60 \%$ of the body length from the snout in adult female right whales.

On their own and in the context of other large whale body condition studies, these findings demonstrate that photogrammetric measurements of dorsal body shape are effective as quantitative assessments of nutritive condition of free-swimming right whales. The results also suggest that this technique could be used to detect pregnancies that may otherwise be missed, which would provide a more accurate assessment of the variability in Eubalaena glacialis reproduction. Overall, such a non-invasive, remote, quantitative tool is highly relevant for testing hypotheses regarding nutritive condition, the results of which are needed for developing and implementing effective management strategies to aid the conservation of $E$. glacialis.

Acknowledgements. M. Lynn, C. Stinchcomb, J. Gilpatrick and P. Olsen assisted with collection and organization of the photographs, instruction of photogrammetric methods and all of the work put into organizing the calibration and right whale identification data. P. Jantzen of Media Cybernetics developed the Image Pro Plus macro that semi-automated the segmentation of the whales. The New England Aquarium's right whale research project, particularly H. M. Pettis, 
identified and confirmed the identification of the North Atlantic right whale females. The North Atlantic Right Whale Consortium provided access to the 29 June 2004 version and the 25 February 2011 version of the North Atlantic Right Whale Consortium database. We thank the pilots and field assistants in both the USA and South Africa for making the collection of the photographs possible. J. Y. Wilson provided an invaluable review of this manuscript as did C. A. Miller's dissertation committee: D. A. Pabst, M. W. Brown, V. E. Dionne, E. P. Widmaier and T. H. Kunz. A. L. Bogomolni drew the diagram of the right whale for Fig. 1. We also acknowledge 5 anonymous reviewers whose thorough efforts significantly improved the manuscript. This project was made possible with funds provided by the National Oceanic and Atmospheric Administration (NOAA), National Marine Fisheries Service, the Northeast Consortium, and the Hussey Foundation through the Ocean Life Institute at Woods Hole Oceanographic Institution. The photogrammetric work in South Africa also was made possible by a grant to P.B.B. from the International Whaling Commission and authorization was provided according to the provisions of the Sea Fisheries Act, 1973, by the Director of Sea Fisheries, permits issued to P.B.B. 22 April 1988 and 02 June 1989. The photogrammetric work on Eubalaena glacialis was undertaken under Marine Mammal and Endangered Species Scientific Permit No. 917 to the NOAA National Marine Fisheries Service, Northeast Fisheries Science Center.

\section{LITERATURE CITED}

Aguilar A, Borrell A (1990) Patterns of lipid content and stratification in the blubber of fin whales (Balaenoptera physalus). J Mammal 71:544-554

Barb CR, Kraeling RR, Rampacek GB (2001) Nutritional regulators of the hypothalamic-pituitary axis in pigs. Reprod Suppl 58:1-15

Barb CR, Hausman GJ, Lents CA (2008) Energy metabolism and leptin: effects on neuroendocrine regulation of reproduction in the gilt and sow. Reprod Domest Anim 43:324-330

Baumgartner MF, Mate BR (2003) Summertime foraging ecology of North Atlantic right whales. Mar Ecol Prog Ser 264:123-135

Belyea RL, Frost GR, Martz FA, Clark JL, Forkner LG (1978) Body composition of dairy cattle by potassium-40 liquid scintillation detection. J Dairy Sci 61:206-211

Best PB (1994) Seasonality of reproduction and the length of gestation in southern right whales Eubalaena australis. J Zool 232:175-189

> Best PB (2000) Coastal distribution, movements and site fidelity of right whales Eubalaena australis off South Africa, 1969-1998. S Afr J Mar Sci 22:43-55

Best PB (2006) The presence of right whales in summer on the west coast of South Africa: the evidence from historical records. Afr J Mar Sci 28:159-166

Best PB (2007) Whales and dolphins of the Southern African subregion. Cambridge University Press, Cape Town

Best PB, Rüther H (1992) Aerial photogrammetry of southern right whales, Eubalaena australis. J Zool 228:595-614

Best PB, Brandão A, Butterworth DS (2001) Demographic parameters of southern right whales off South Africa. J Cetacean Res Manag 2(Spec Issue):161-169

Bose N, Lien J (1989) Propulsion of a fin whale (Balaenoptera physalus): why the fin whale is a fast swimmer.
Proc R Soc Lond B Biol Sci 237:175-200

Burnell SR, Bryden MM (1997) Coastal residence periods and reproductive timing in southern right whales. J Zool 241:613-621

> Crocker DE, Webb PM, Costa DP, Le Boeuf BJ (1998) Protein catabolism and renal function in lactating northern elephant seals. Physiol Zool 71:485-491

Cubbage JC, Calambokidis J (1987) Size-class segregation of bowhead whales discerned through aerial stereophotogrammetry. Mar Mamm Sci 3:179-185

Devore JL (1995) Probability and statistics for engineering and the sciences. Duxbury Press, Pacific Grove, CA

Dunkin RC, McLellan WA, Blum JE, Pabst D (2010) The buoyancy of the integument of Atlantic bottlenose dolphins (Tursiops truncatus): effects of growth, reproduction, and nutritional state. Mar Mamm Sci 26:573-587

Feltmann CF, Slijper EJ, Vervoot W (1948) Preliminary researches on the fat-content of meat and bone in blue and fin whales. Proc K Ned Akad Wet 51:604-615

> Firestone J, Lyons SB, Wang C, Corbett JJ (2008) Statistical modeling of North Atlantic right whale migration along the mid-Atlantic region of the eastern seaboard of the United States. Biol Conserv 141:221-232

> Frisch RE (1984) Body fat, puberty and fertility. Biol Rev Camb Philos Soc 59:161-188

> Gales R, Renouf D (1994) Assessment of body condition of harp seals. Polar Biol 14:381-387

Gittleman JL, Thompson SD (1988) Energy allocation in mammalian reproduction. Am Zool 28:863-875

> Hamilton PK, Cooper LA (2010) Changes in North Atlantic right whale (Eubalaena glacialis) cow-calf association times and use of the calving ground: 1993-2005. Mar Mamm Sci 26:896-916

Hamilton PK, Marx MK, Kraus SD (1995) Weaning in North Atlantic right whales. Mar Mamm Sci 11:386-390

Hamilton PK, Knowlton AR, Marx MK (2007) Right whales tell their own stories: The photo-identification catalog. In: Kraus SD, Rolland RM (eds) The urban whale: North Atlantic right whales at the crossroads. Harvard University Press, Cambridge, MA, p 75-104

- Haug T, Lindstroem U, Nilssen KT (2002) Variations in minke whale (Balaenoptera acutorostrata) diet and body condition in response to ecosystem changes in the Barents Sea. Sarsia 87:409-422

Hill JW, Elmquist JK, Elias CF (2008) Hypothalamic pathways linking energy balance and reproduction. Am J Physiol Endocrinol Metab 294:E827-E832

Ichii T, Shinohara N, Fujise Y, Nishiwaki S, Matsuoka K (1998) Interannual changes in body fat condition index of minke whales in the Antarctic. Mar Ecol Prog Ser 175: $1-12$

IWC (International Whaling Commission) (2001) Report of the workshop on the comprehensive assessment of right whales: a worldwide comparison. J Cetacean Res Manag 2(Spec Issue):1-60

Knowlton AR, Kraus SD (2001) Mortality and serious injury of northern right whales (Eubalaena glacialis) in the western North Atlantic Ocean. J Cetacean Res Manag 2(Spec Issue):193-208

> Koopman HN, Pabst DA, McLellan WA, Dillaman RM, Read AJ (2002) Changes in blubber distribution and morphology associated with starvation in the harbor porpoise (Phocoena phocoena): evidence for regional differences in blubber structure and function. Physiol Biochem Zool 75:498-512 
Koski WR, Davis RA, Miller GW, Withrow DE (1992) Growth rates of bowhead whales as determined from low-level aerial photogrammetry. Rep Int Whaling Comm 42: 491-499

Kraus SD, Moore KE, Price CA, Crone MJ, Watkins WA, Winn HE, Prescott JH (1986) The use of photographs to identify individual North Atlantic right whales (Eubalaena glacialis). Rep Int Whaling Comm (Spec Issue 10): 145-151

Kraus SD, Hamilton PK, Kenney RD, Knowlton A, Slay C (2001) Reproductive parameters of the North Atlantic right whale. J Cetacean Res Manag 2(Spec Issue): 231-236

Kraus SD, Brown MW, Caswell H, Clark CW and others (2005) North Atlantic right whales in crisis. Science 309: 561-562

Kraus SD, Pace RM, Frasier TR (2007) High investment, low return: the strange case of reproduction in Eubalaena glacialis. In: Kraus SD, Rolland RM (eds) The urban whale: North Atlantic right whales at the crossroads. Harvard University Press, Cambridge, MA, p 172-199

Lockyer C (1981) Growth and energy budgets of large baleen whales from the southern hemisphere. In: Gordon Clark J (ed) Mammals in the seas; general papers and large cetaceans, Vol 3. FAO, Rome, p 379-488

Lockyer C (1986) Body fat condition in Northeast Atlantic fin whales, Balaenoptera physalus, and its relationship with reproduction and food resource. Can J Fish Aquat Sci 43:142-147

Lockyer C (1987) The relationship between body fat, food resource and reproductive energy costs in North Atlantic fin whales (Balaenoptera physalus). Symp Zool Soc Lond 57:343-361

Lockyer CH, McConnell LC, Waters TD (1984) The biochemical composition of fin whale blubber. Can J Zool 62:2553-2562

Lockyer CH, McConnell LC, Waters TD (1985) Body condition in terms of anatomical and biochemical assessment of body fat in North Atlantic fin and sei whales. Can J Zool 63:2328-2338

Marshall F, Hammond J (1926) The physiology of animal breeding, with special reference to the problem of fertility. Ministry of Agriculture and Fisheries, London

Mate BR, Best PB, Lagerquist BA, Winsor MH (2011) Coastal, offshore, and migratory movements of South African right whales revealed by satellite telemetry. Mar Mamm Sci 27:455-476

$>$ Mellish JE, Iverson SJ (2001) Blood metabolites as indicators of nutrient utilization in fasting, lactating phocid seals: Does depletion of nutrient reserves terminate lactation? Can J Zool 79:303-311

Mellish JE, Iverson SJ, Bowen WD (1999) Variation in milk production and lactation performance in grey seals and consequences for pup growth and weaning characteristics. Physiol Biochem Zool 72:677-690

Mendez J, Keys A (1960) Density and composition of mammalian muscle. Metabolism 9:184-188

Miller CA, Reeb D, Best PB, Knowlton AR, Brown MW, Moore MJ (2011) Blubber thickness in right whales Eubalaena glacialis and Eubalaena australis related with reproduction, life history status and prey abundance. Mar Ecol Prog Ser 438:267-283

Moore MJ, Knowlton AR, Kraus SD, McLellan WA, Bonde RK (2004) Morphometry, gross morphology and available histopathology in North Atlantic right whale (Eubalaena glacialis) mortalities (1970 to 2002). J Cetacean Res Manag 6:199-214

> Moore M, Walsh M, Bailey J, Brunson D and others (2010) Sedation at sea of entangled North Atlantic right whales (Eubalaena glacialis) to enhance disentanglement. PLoS ONE 5:e9597

Næss A, Haug T, Nilssen EM (1998) Seasonal variation in body condition and muscular lipid contents in northeast Atlantic minke whale Balaenoptera acutorostrata. Sarsia 83:211-218

NOAA (National Oceanic and Atmospheric Administration) (2009) Stock assemment report: North Atlantic right whale (Eubalaena glacialis): western Atlantic stock. www.nmfs.noaa.gov/pr/pdfs/sars/ao2009whnr-w.pdf (accessed 6 Nov 2010)

Nousek-McGregor AE (2010) The cost of locomotion in North Atlantic right whales Eubalaena glacialis. PhD dissertation, Duke University, Durham, NC

Nowacek DP, Johnson MP, Tyack PL, Shorter KA, McLellan WA, Pabst DA (2001) Buoyant balaenids: the ups and downs of buoyancy in right whales. Proc Biol Sci 268:1811-1816

> Oftedal OT (2000) Use of maternal reserves as a lactation strategy in large mammals. Proc Nutr Soc 59:99-106

Omura H, Oshumi S, Nemoto T, Nasu K, Kasuya T (1969) Black right whales in the North Pacific. Sci Rep Whales Res Inst Tokyo 21:1-78

Payne R, Brazier O, Dorsey EM, Perkins JS, Rowntree VJ, Titus A (1983) External features in southern right whales (Eubalaena australis) and their use in identifying individuals. In: Payne R (ed) Communication and behavior of whales, Vol 76. Westview Press, Boulder, CO, p 371-445

Perryman WL, Lynn MS (2002) Evaluation of nutritive condition and reproductive status of migrating gray whales (Eschrichtius robustus) based on analysis of photogrammetric data. J Cetacean Res Manag 4:155-164

Pettis HM, Rolland RM, Hamilton PK, Brault S, Knowlton AR, Kraus SD (2004) Visual health assessment of North Atlantic right whales (Eubalaena glacialis) using photographs. Can J Zool 82:8-19

Phleger CF (1991) Biochemical aspects of buoyancy in fishes. In: Hochachka PW, Mommsen TP (eds) Biochemistry and molecular biology of fishes, Vol 1. Elsevier Science, Amsterdam, p 209-247

Pine AP, Jessop NS, Oldham JD (1994) Maternal protein reserves and their influence on lactational performance in rats. Br J Nutr 71:13-27

Prunier A, Quesnel H (2000) Nutritional influences on the hormonal control of reproduction in female pigs. Livest Prod Sci 63:1-16

- Read AJ (1990) Estimation of body condition in harbour porpoises, Phocoena phocoena. Can J Zool 68:1962-1966

Reeves RR, Mitchell E (1986) The Long Island, New York, right whale fishery: 1650-1924. Rep Int Whaling Comm (Spec Issue 10):201-213

Reeves RR, Rolland RM, Clapham PJ (2001) Causes of reproductive failure in North Atlantic right whales: new avenues of research. Report No. 01-16. Northeast Fisheries Science Center, Woods Hole, MA

> Reist JD (1985) An empirical evaluation of several univariate methods that adjust for size variation in morphometric data. Can J Zool 63:1429-1439

Rice DW, Wolman AA (1971) The life history and ecology of the gray whale (Eschrichtius robustus). Spec Publ No. 3. American Society of Mammalogists, Stillwater, OK 
Right Whale Consortium (2004) North Atlantic right whale consortium identification database v. 06/29/2004. New England Aquarium, Boston, MA

Right Whale Consortium (2011) North Atlantic right whale consortium identification database v. 02/25/2011. New England Aquarium, Boston, MA

Robbins CT (1993) Wildlife feeding and nutrition. Academic Press, Boston, MA

Rowntree VJ, Payne RS, Schell DM (2001) Changing patterns of habitat use by southern right whales (Eubalaena australis) on their nursery ground at Peninsula Valdes, Argentina, and in their long-range movements. J Cetacean Res Manag 2(Spec Issue):133-143

Sumich JL, Goff T, Perryman WL (2001) Growth of two captive gray whale calves. Aquat Mamm 27:231-233

Editorial responsibility: Michael Castellini,

Fairbanks, Alaska, USA
Swick RW, Benevenga NJ (1977) Labile protein reserves and protein turnover. J Dairy Sci 60:505-515

Thomas VG (1990) Control of reproduction in animal species with high and low body fat reserves. In: Frisch R (ed) Adipose tissue and reproduction, Vol 14. Karger, Basel, p 27-41

Wade GN, Schneider JE (1992) Metabolic fuels and reproduction in female mammals. Neurosci Biobehav Rev 16:235-272

Woodward BL, Winn JP, Fish FE (2006) Morphological specializations of baleen whales associated with hydrodynamic performance and ecological niche. J Morphol 267: 1284-1294

Young RA (1976) Fat, energy and mammalian survival. Am Zool 16:699-710

Submitted: October 8, 2009; Accepted: February 15, 2012

Proofs received from author(s): July 4, 2012 